\title{
聽器脂肪物質二關スル實驗的研究
}

\section{第三報告 炎症}

H. Nakamura: Experimentelle Untersuchungen über die Fettsubstanzen im Gehörorgan.

III. Mitteilung: Über die Fettsubstanz im entzündeten Gelı̈rorgan des Meerschweinchens.

岡山缺科大學耳鼻咽喉科教室（主任 田中数授)

研究科學生

醫學士中村 博鄉

目次

一. 緒 言

二. 酤驗方法

三. 筫驗枳綪

（1）非䋥得性炎症二 於タッ所見

(2) 紴藏性炎症二
四. 總括亚二考案

五. 結

引用書目

附圖䛃明

附圆

言

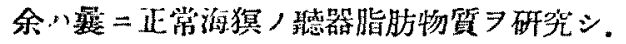

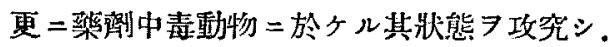

(13)筧性所見トシテ㯖器一定部位二脂肪物質，出

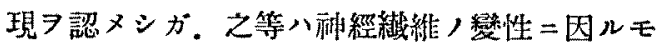

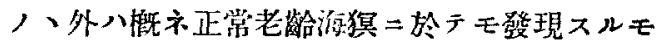

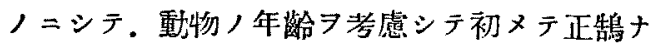
ル判㝴シ下シ得ルモノナル事ヨ知レリ。

然ラバ炎定性變化二於テハ如何。そレ當然次=

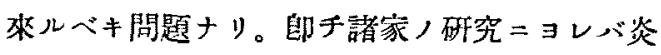
症性病湭二八一般二著明八脂肪物質儿山現习認 ムルモノニシテ(川村(6). チャチォ(1) . 我項域 二於テモ游江田 ${ }^{(5)}$ ，慢性上顎窗炎二於々儿脂肪

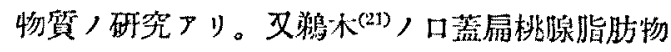
質二關スル研究モ。其炎症性機轉卜密接ナル關

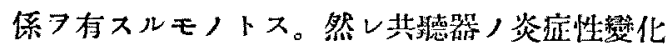

二於タル脂肪物質二就キテハ末ダえヨ研究七ル モノアルタ聞カズ。

而シテ聽器殊＝內耳ハ一般＝血液內物質ノ移行 シ難キ器官ニシテ內耳生體染色が通常, 方法= ヨリテハ陰性ナルハ之二原因スルモノナルガ. 中道 ${ }^{(10)}$ ，實驗的研笑 $=\exists$ レバ其關係八脂肪物質 二對シテモ同樣ナり。然ルニ一方坂元 ${ }^{(16)}$ 中道 ノ聽器生體染色二關スル經驗ニヨレバ迷路炎, 存在スル場合八色素ノ取移行甚ダ容易トナル フ以テ同一條件二於ヶル脂肪物質，出現，有然 八興味アル問題タルョ失ハズ。蓋シ現今一般 見解二從一バ脂肪沈着八刎諭. 脂肪變性 =於テ モ其脂肪物貿へ主トシテ血液ニヨリテ供給サル ル㐆ナリトス。

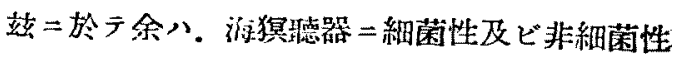




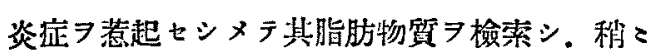
興味アル所見习得タルラ以テ立二之レヨ報告七 ントス。

\section{二實羷方法}

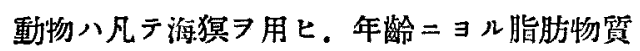
ノ出現 $フ$ 除外センガ篇メ=體重 $350 \mathrm{~g}$ 乃至 500 $\mathrm{g} / モ ノ \ni$ 使用七リ。

起炎方法トシテハ非細菌性炎症二對シテハ「ク ロ、フォルム」外聽道注入法フ迩ビ. 細菌性炎 应二對シテ八菌浮游液

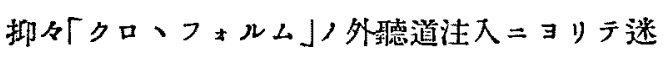
路機能 7 照置シ得,事八既二古クョリ知ラレタ レド、えガ單ナル機能的障碍ニ非ズシテ組織的継 化二因ルモノナル事八田中教授 ${ }^{(19)}$ 人初メテ洼意 七ラレシトコロニシテ其後高崎 ${ }^{(18)}$.エッケル(3).

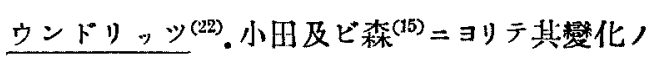
詳細 7 知り得タルガ. 其成績 $=ヨ$ ン゙゙其本態八 迷路/炎症性變化ニシテ. 且ッ此際外耳及ビ中 耳二モ著明ノ炎症 究目的ニハ甚ダ適㗬セル方法卜言フベキナリ。 唯此際一應考慮スべキ八脂肪物質二關スル赛驗 的研究二當り脂肪溶解劑タル「ク口、フォルム」 ア使用スル事ニアレド. 余八多數斬物二就キテ 豫備試駿 結果外㯖道二「クロ、フォルム」7

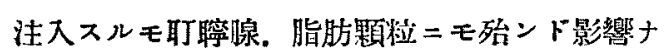
ク. 中耳及ビ內耳ノ脂肪物質二對シテ八全ク何 等ノ直接作用

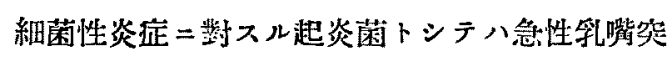
起炎患者ヨリ分離七儿橫色葡萄彇球菌 7 用七其 寒天科面培養 24 時間 $モ$ モ 1 白金耳 7 生理的 食監水二浮游七シメ鼓膜习通シテロ耳腔＝注入 七。
之等ノ處置习施セル動物ハ何しモ種々ナル經過

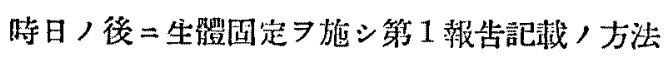

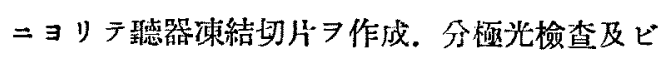
各種, 脂肪染色二ヨリテ脂肪物質，分布习研究

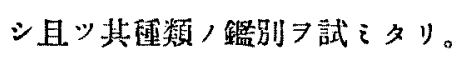

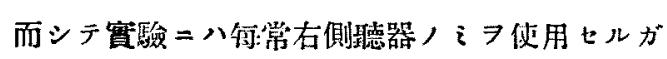

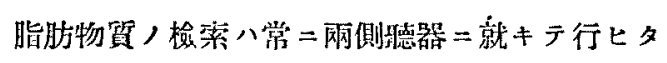

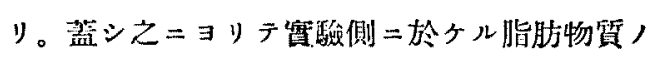
消長ガ局所原因二ヨルカ. 或八全身的影響 $=ヨ$ ルカラ祭知シ得ベケレバナリ。

\section{三. 實 䌞 成 績}

宦䮑䡃物ノ「クロ、フォルム」又八細菌浮游液

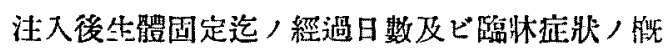
耍八次表，如シ。

以下之等各動物二於ケル所見，概要习述ブべ i。

\section{（1）非細菌性炎症二於々几所見}

第 5 號游㩧 (注入後 3 時間)

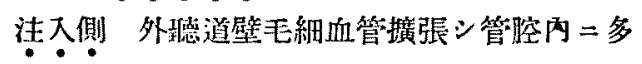

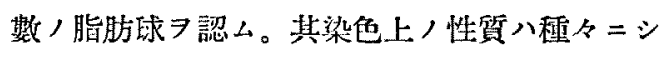
テ「ズダン」ンヨリラ满亦色二染り單屈折性ナレ ド「「ニイルブラウ」ニヨリテ青奖色乃至青色 呈シ。各種ハリボイド」染色法二對シ陽性ナル モノト，㓌性ナルモノト存在セり。

鼓膜二罢常ナク中耳腔二八極メテ少量，㵶維素 性ノ出物アリ。

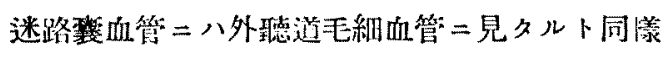
入脂肪物質ア有スルモノアリ。螖牛悫二於テハ 下方迴轉殊二第 1 廻轉鼓室階及ビ前庭階二少量 ，㵶維素性洷甠物アルモ上力速轉二於テハ之 認メズ。蝸牛管八第 1 畐轉二於デコルチ器破壤 セラレ内淋巴整內＝少量，赤血球 認ムルモ脂 


\begin{tabular}{|c|c|c|c|c|c|c|c|c|}
\hline \multirow{2}{*}{$\begin{array}{l}\text { 動物 } \\
\text { 番號 }\end{array}$} & \multirow{2}{*}{ 體 重 } & \multirow[t]{2}{*}{ 性 } & \multirow{2}{*}{ 炎淀，種類 } & \multirow{2}{*}{$\begin{array}{l}\text { 起炎後 } \\
\text { 生存時日 }\end{array}$} & \multicolumn{2}{|c|}{ 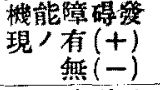 } & \multicolumn{2}{|c|}{ 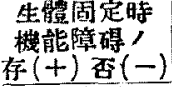 } \\
\hline & & & & & 聽能 & $\begin{array}{l}\text { 前麇 } \\
\text { 機能 }\end{array}$ & 㯺能 & $\begin{array}{l}\text { 前庭 } \\
\text { 脒能 }\end{array}$ \\
\hline 5 & 443 & 우 & 非細菌性 & 3 時 间 & + & + & + & + \\
\hline 1 & 382 & $\hat{\sigma}$ & " & 6 時 阔] & + & + & + & + \\
\hline 4 & 367 & $\hat{\delta}$ & " & 12 時閒 & + & + & + & + \\
\hline 2 & 395 & $\hat{\delta}$ & $"$ & 24 時間 & + & + & + & + \\
\hline 3 & 361 & $\hat{\sigma}$ & $"$ & 48 㻉閑 & + & + & + & + \\
\hline 6 & 417 & $\hat{\delta}$ & $"$ & 4 日 & + & + & + & + \\
\hline 12 & 327 & 우 & $"$ & 4 日 & + & + & + & + \\
\hline 7 & 464 & $\hat{\jmath}$ & $"$ & 5 日 & + & + & + & + \\
\hline 16 & 415 & 우 & $"$ & 10 日 & + & + & + & + \\
\hline 15 & 423 & $\boldsymbol{s}$ & " & 1 名 & + & + & + & + \\
\hline 13 & 338 & $\hat{\jmath}$ & " & 3 月 & + & + & + & + \\
\hline 23 & 431 & 우 & 积菌 性 & 3 的間] & + & - & + & - \\
\hline 21. & 366 & $\hat{\boldsymbol{\sigma}}$ & $"$ & 6 時 閒 & + & - & + & - \\
\hline 25 & 364 & 占 & $"$ & 12 時 閑 & + & - & + & - \\
\hline 24 & 367 & +8 & " & 24 時閒 & + & - & + & - \\
\hline 27 . & 384 & $\hat{\boldsymbol{s}}$ & " & 48 時間 & + & + & + & + \\
\hline 26 & 355 & $\boldsymbol{\delta}$ & $"$ & 日 & + & + & + & + \\
\hline 31 & 429 & 우 & " & 日 & + & + & + & + \\
\hline 22 & 410 & $\hat{\delta}$ & " & 10 日 & + & - & + & - \\
\hline 33 & 426 & + & " & 10 日 & + & + & + & + \\
\hline 35 & 407 & $\delta$ & $"$ & 15 日 & + & + & + & + \\
\hline 36 & 402 & 우 & $"$ & 20 日 & + & + & + & - \\
\hline 32 & 395 & $\hat{\sigma}$ & " & 1 夕月 & + & - & + & - \\
\hline 39 & 352 & 우 & $" 1$ & 2 万 月 & + & - & + & - \\
\hline 41 & 357 & 우 & 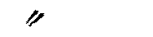 & 3 ヶ月牛 & + & - & + & - \\
\hline
\end{tabular}

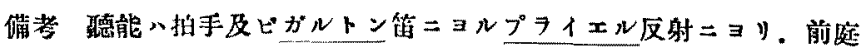

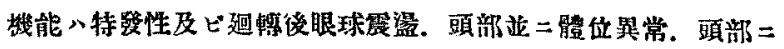
歯スル迷路性向位反射及ビ代僧性眼球運動 狀況二ヨリ其障碍 ノ有無キ刵定をり。
肪染色上ニ八较化ナシ。

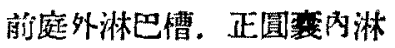
巴質二モ少量，㵶維素性渗 出物厂リテ正圆变㯖珓上皮 細胞膨化シ。其基貿/毛細 管二血球及ビ脂肪物質 $\ni$ 充 滿七ルモノアリ。其性䓄方 外糔滇壁毛細管二於ナルモ 人ト同一ナリ。第 2 鼓膜.

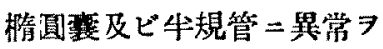
認メズ。矛㯖神經及ビ同節細 胞二モ變化ナク異常，脂肪. 物睤 出現

韭注入側聼器 $=八$ 何等 變化习認メズ。

\section{第1 1 號游猽}

(注入後 6 時間)

注入側 所見八概衣第 5 號卜同阥ナレド，其變化八

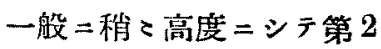
鼓膜, 内面二八㮐飞多量，

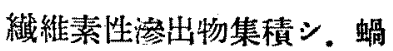
牛殼第 1 䢙轉 =於ケルコル 千器，破㥋モ著シク骨螺旋 板内血管二脂肪物質 7 認 么。正圓讓辐琣＝八上皮， 膨化アレド，楕圓蒦及ビ牛 規管二八異常ナク．疆神經 及ビ同節細胞 =モ變化 7 認 メズ。

非注人側 全ク正常卜異 ナラズ。

第出號源猽 


\section{（注大後12時閒）}

注大側 外宗㥁道皮下組織二八多數ノ多㤥白血 球遊出シ，其原形質二多數 脂肪顆粒 7 認么。 其性質八「ズダン」=ヨリテ黃赤色. 「ニイル ブラウ」ニヨリテ青色 7 呈シ. 單属折性ニシテ フイシュレル. スミス・デイトリッヒ. 瀨川ノ 各法及ビ「ノイトラルロート」陽性ナルモノ多 キモ. 佁ボ等ノ方法二㓌性ナルモノ 鼓膜八所々二於テ表皮膨隆シ。之卜固有層卜ノ 間二㧳液性渗出物アリテ. 其內二遊出七儿白血

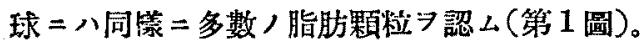
中耳腔ニモ少量ノ繊維素ノ柝出アリテ居と脂肪 顆粒 $习$ 有スル多核白血球ノ之二附着七ルラ認 么(第 1 温)。中耳粘膜八稍 2 浮腫狀二腫脹之. 粘膜下組織二同棱ナル多核白血球遊出セリ。 鼓膜㖘筋モ同樣二脂肪顆柆 $ᄏ$ 有スル多核白血球 ノ浸潤フ蒙リ．且ツ其腱細胞ノ兩端ニモ之ト同 一性狀 7 有スル脂肪顆粒出現セり(第6圖參照)。

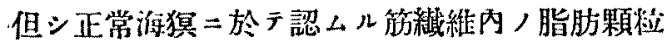
ニ八何等钹化ナシ。

螖牛殼二於テ八第 2 鼓膜，結締織㵶維獥化シ。 多核白血球ノ浸潤习蒙リタルノてナラズ. 其内 面二モ炎㱏性滲出細胞集合シ之等八何レモ其原 形質 =多數 $/$ 脂肪顆粒 7 有シ。其性質八外聽道 二見タルモ，卜同一ナリ。コルチ器八第 1 呬博 ニ於テ八全ク破壤セラレ，上方䢙轉二於テモ其 .構造不明瞭トナリ．蝸牛管二少量ノ赤血球及ビ 繊維素フ認ム。鼓室階二八殊二下方迴轉二於テ

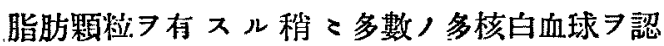
ムルモ。前庭階及ビ上方廻轉，螖牛管．前庭外

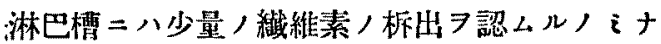

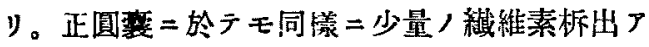
リテ其㯖玟上皮細胞ノ棈浩稍
モ脂肪染色上ニ八變化ナシ。

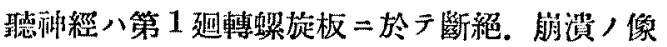
ア是シ. 髓球

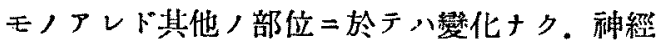
節細胞ニモ異常ヨ認メズ。

非注入側 何等認ムベキ變化ナシ。 等 2 號海爆 (注入挠 24 時間)

洁入側 外軻道二於ケル所見八第 4 號ト咯々

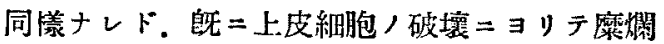
ア形成七ルモノアリ。鼓膜及ビ中耳粘膜二於ヶ ル所見モ略 ? 第 4 號ト同ジク，中耳腔二遊出七 ル多核白球八其數 7 增加シ其原形質 $=$ 同㥄 $=$ 脂 肪顆粒习有入。鼓膜张筋モ同樣二著明，多核白 血球ノ浸潤习受ケ其原形貿二脂肪顆柆 外. 其腱細胞ノ核ノ网端 $=モ$ 同羕ナル性質 7 有 ス几脂肪顆粒出現七り。

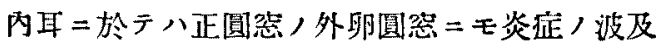
ᄏ認メ．鐙骨前庭關節軟骨細胞=モ脂肪顆精出 現シ.「ズダン」ニテ黄赤色.「ニイルブラウ」= テ青色二染リ。スぇス・ディトリッヒ. 瀨川法

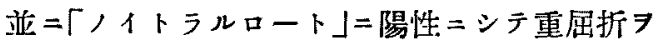
是セズ(第 7 圆及ビ第 8 踾蕏照)。 蝸牛殼 $=$ 於テ八第 2 鼓膜，内側 $=$ 多核白血球集 合七儿外. 下方廻轉，鼓室道二八血性繊維素性 滲出物厂リ。且ツ多㤥白血球，接出 7 認又. 上方迴轉，鼓室階茾二前庭階及ビ螖牛管二八同 一性貿ノ渗出物アルモ炎症性渗出細胞 ズ。之等，部位二遊出七ル多核白血球八何レモ 其原形質内 $=$ 脂肪顆粘 7 有ス。コルチ器八第 1 迴轉二於テ八全ク破壤七ラレテ其形態 $\boldsymbol{\text { 留メ }}$ ズ。上方呬轉二於テモ其權造不明膫トナリ有毛 細胞破液消失七ルモ異常, 脂肪物質, 出現 7 認 メズ。 


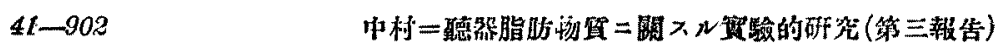

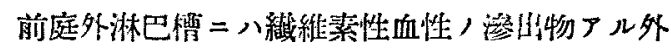

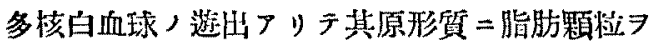

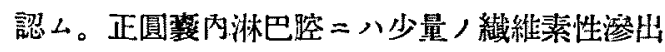

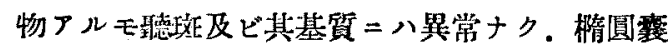
及ビ牛規管外淋巴腟ニ八少数ノ赤血球》認ム。

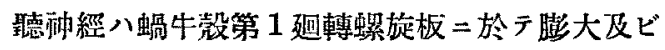

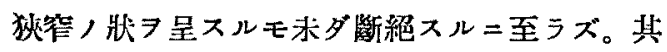

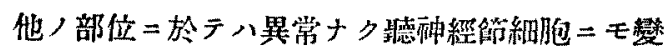
化 $\ni$ 認メズ。

韭注入側 畺器八全々正常ナリ。

第 3 號海猽 (注入後 48 時間)

外聽道二於ケル所見八略 、第 2 號二同ジ。鼓

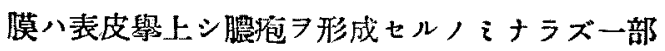

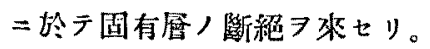

中耳粘膜八腫脤シ細胞浸潤アリ。多核白血球， 他多数ノ單核圆形細胞厂リテ其核八偏在性ニシ テ答䠞形テナシ。「クロマチン」ニミシク其原形 質二八多核白血球卜同儀ナル脂肪顆粒 モ夫レョリモ顆䊀ノ大ナルモノ多シ。カ、ル單 核緗胞八中耳腔內滲出物中二モ多核白血球 $=$ 混 ジテ存在七り。炎症八又歐氏管周圍二波及シ。 此部位二於广系血管內腔及ビ內被緗胞二脂肪顆 粒 スル多核白血球遊出七り。

內耳二於ヶル所見八略 ?第 2 號卜同一ナレド本

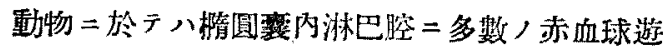

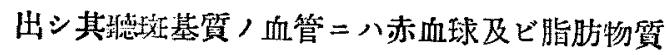

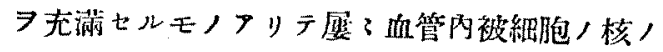
兩端 ニモ脂肪顆粒 7 認ム。

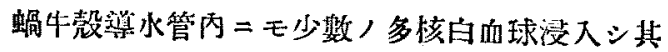
原形留二脂肪顆粠ヨ認し。

非洼入側 全ク㲋化フ認メズ。 第6 號海猽（注大後 4 日）

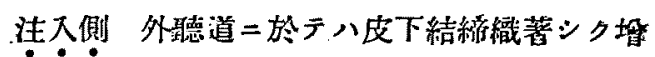
殖シ多数，幼弱結締織細胞現ハレ其核，兩端二 脂肪顆竝 「ニイルブラウ」こテ青色ア星シ單屈折性ニシテ フイッシェレル. ス、ス・ディトリのヒ. 瀨川 ノ各法及ビ「ノトトラルロート」陽性ノモノ多 キモ時ニ之等ノ染色法二陰性ノモノフ認ム。鼓 膜八表皮ノ剩哟ア来シタルモ圆有膜ハョク保存 セラレタリ。

中耳二於子几所見八第 2 號卜略、同樣ナレド粘 膜下組織 $=$ 結綗織細胞ノ增殖习認ムルノiナラ ズ中耳腔内，繊維素性洷出物二モ組織化始マリ 奻弱ナル結締織細枹出現シ。之等八何レモ其栚 八雨端. 時二八原型質全般二亘り脂肪顆粘: 7 認 メ其性質八外聽道二於テ見タルモ，ト全ク同一 ナ.リ。小聽骨筋內二八結締織細胞增殖シ，觔織 維內二ハ㱠ンド脂肪顆粠シ認メザル二区シ。其 腱細胞及ビ增殖セル結䋨織細胞, 核ノ兩端二八 脂肪顆垃出現七リ。

第 2 鼓膜ニ於少ル所見八第 3 號卜大苃ナシ。 蝸牛款ニ於テハラィスネル膜輕度二舉上シ．第

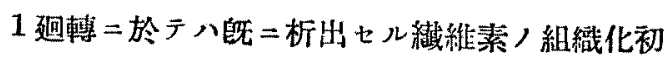
マリ鼓室階中二多數, 幼弱結締織細胞現ハレ。

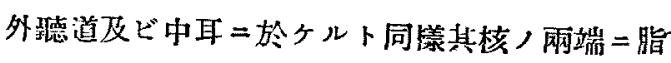

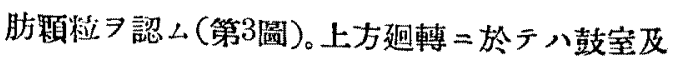
ビ前虐兩階共赤血球及ビ多侅白血球 組織球性細胞出現シテえア捕食セルモ脂肪顆愔 八比較的少シ。コルチ器八第 1 迴輤二於テハ全 ク破壇セラレ螖牛管中＝多数ノ赤血球及ビ多核 白血球蓝二組織球性細胞厂リテ後 2 者ノ原形質 二八多數 脂肪顆糕习認ム。カ、ル部位二於テ ハライスネル膜 =モ同樣二脂肪顆粞出現七り。

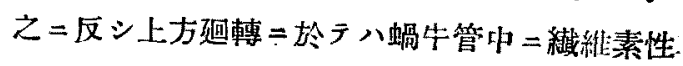


參出物アリテコルチ器八其綝胞ノ模造不明瞭卜 ナレルモ南ホヨク其外形 7 存シ異常/脂肪物質 ノ出現ヨ認メズ。

前庭領域＝於ケル所見八第 3 號卜略 、同樣ナレ

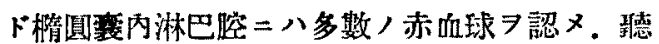
斑上皮膨化シ其基質 $=$ 結 䋨 織 細胞 增殖 7 認 $\llcorner$ 。

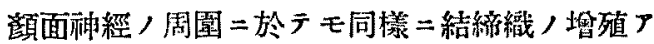
リテ约弱ナル結締織細胞，核，雨端二脂肪顆烧 認ム。

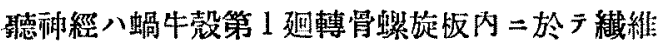
ノ崩謴 7 認メ。多數ノ組織球性細胞出現シテ骨遀

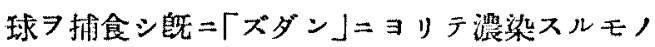
アリ。党該蝃旋神經節細胞二八細胞周圍=空隙 ヨ有スルモノアレド脂肪顆䊀ヨ有スルモノナ ク. 其他ノ部位二於テ八螖牛殼並二前庭神經及 ビ兩神經䈃細胞二翼常

螎牛殼導水管中二八鼓空階開口部ヨリ多數ノ多 核白血球侵入シ且ツ組織球性細胞/之 7 捕食七 ルモノアリテ爾省共 $=$ 脂肪顆糔 蜘蛛膜下膑ニ近ッ゙クニ從テ絧狀織細胞及ビ內骨 膜結䅧織細胞增殖シ塚二管腔习閉塞シ。等， 网種 細胞二於テモ同榡二其核, 网端二脂肪顆 䊀习認ム(第 14 圖參照)。

非注入側 二八全ク買常ヨ認メズ。 第12號河猽 (注入後 4 日)

注入侧 外㝥道及ビ中耳二於ケル所見八略 : 第 6 號ト同一ナレド炎症八正圆空及ビ卵圆息》 經テ內耳二侵入シ蝸牛殼=於テ八殊=第 1 迴轉 コルチ器全り破壞セラレ螺等靶帶二著明，結縞 糡/新生 7 認么。第 1 迴轉蝒旋神經八炎症/侵

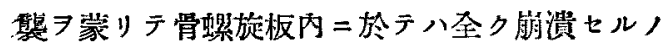

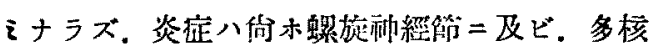

白血球ノ浸潤及ビ結締織ノ增殖フ認メ。神經節

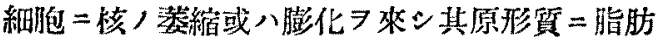

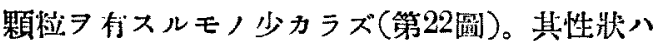
焉二「アトキシール」中毒海猽或八老年海猽＝認

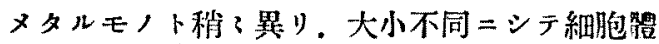
內二散在シ. 或八崩溃二傾キテ不明瞭トナレル 原形質限界ヨ越エテ外二出デタルモノアルノえ ナラズ. 染色上二モ美異つリラ「ズダン」ニヨリ テ黃赤色.「ニ1ルブラウ」ニヨリテ紫色 「リポイド染色法ニハ陰性ナリ。 鼓意．前庭网階二於少ル戀化八略、第 6 號=同 ジ。

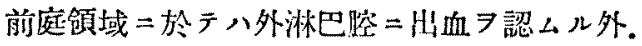
正圆䒼內淋巴腔=少數 $/$ 多核白血球遊出シ。一 部八前庭導水管二蓻シ此處二存在スル特有ナル 大圆形單核細胞ニヨリテ捕食セラレタルモノア り。

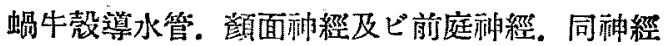
简細胞二於ケル所見八略 ? 第 6 號二同ジ。

悲洼入側 氯器八全ク正常+リ。 第7 號菏猽 (洁入後5日)

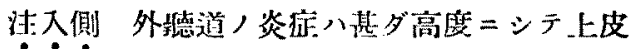
八一部壊死二陷り「ズダン」ニテ一樣二淡ク黃赤 色二染り.「へマトキシリン」ニヨリテ核ノ染色 セラレザル部分アリ。鼓膜八著シク破壤七ラレ 外聽道卜中耳腔卜八庫っ交通ス。中耳二於ケル 所見八略 3 第 6 號二同ジ。

鐙骨前庭關節腔二八多核白血球及ビ組䄉球性細

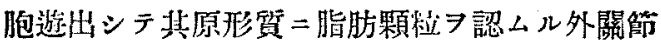
軟骨細胞八其核「へアトキシリン」ニヨリテ染色 セラレズ。

骨性迷路囊/血管八脂肪物質ニヨリテ充霂セラ レ. 詳細二観察スル時八此脂肪物質八一部八遊 
離 =存在シ。一部八内被細胞及ビ管腔內 =存在 スル多核白血球）原形質内 $=ア ル \ni$ 知ル（第17 圖)。

蝸牛殼二於々ル所見八略?第 6 號卜同ーニシテ 同愫=ライスネ儿膜，舉上ヨ認么儿モ外湘巴腔 ニ於ケル出血ハ之レヨリモ高度ナリ。前庭外淋

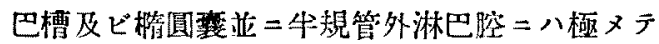

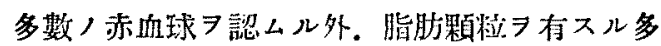
數ノ組織球性細胞遊出七ルノえナラズ. 斯ル細 胞八之等各部ノ內淋巴腔二モ出現七り。

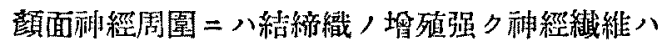

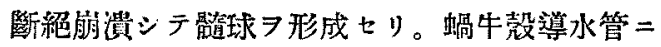
於ケル所胃モ略、第 6 號卜同一ナリ。

非注入側 全ク異常 第 16 號诲猽（注入後 10 日）

注入側 外㯖道二於テハ皮㝊結䋨織著シク增 殖シ新生結締織細胞二八殊二其核,网端二脂肪 顆粒ヨ認ム。鼓膜八破壞セラレ外辐道及ビ中耳 腔二多數ノ多核白血球及ビ組織球性細胞アリ且 ツ幼弱結締織細胞 二多數，脂肪顆柆 少數ノ淋巴細胞フルモ其原形啠買ノ中二八脂肪顆 粒习認ムル事能ハズ。組織球性細胞ハ殊二多核 白血球ノ集國ノ周園＝環狀シナシテ排列ス儿事 多ク其脂肪顆柆八屡、甚ダ多量ニシデ所謂脂肪 顆柆細胞卜認ムベキ狀习是ス。斯ルモノ＝於テ ハ「リポイド染色二㓌性ノ顆柆モ少カラズ。 外聽道及ビ中耳胞，骨壁及ビ水平斗規管二於少 ル骨性迷路慗八破骨細胞ニヨリテ著シク侵蝕セ ラレ其缺損部八結縞織ニヨリテ補橲サレタルガ 此部分＝於テモ絬縍織細胞二多数，脂肪颗柆 認ム。之二反シ破骨細胞八其原形貿「ズダン」=

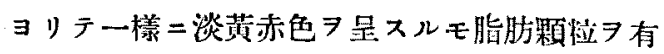

スルモノナシ。中耳＝於ケル其他組織ノ變化ハ 略、第 6 號=同ジ。 螖牛款=於テ八第 1 廻轉鼓宔階及ビ螖牛管亚 = 第 2 鼓膜內側 $=$ 極メテ多數 /多核白血球集合シ 所々二多數ノ幼弱結滴織細胞习認山。殊=第 1 趈轉蝸牛管ニ於テハコルチ器全ク破壤セラレデ 其形䯓フ留メズ。ライスネル膜破レテ其前庭階

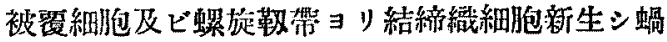
牛管中二侵入シ其核，网端二八同㧼=多數，脂 肪顆粒 ヨ認ム。之二反シ上方廷轉二於テ八戀化 比較的輕度 =シテ前庭. 踥室兩階=少數/赤血 球及ビ炎症性滲出細胞 7 認メ且\%其被镍層ヨリ

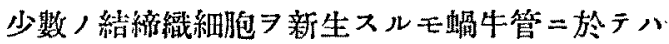
ヨルチ器有毛細胞不鮮明トナレル外著變ナクニ ンゼン細胞ノ脂肪顆程モョク保有セラレタリ。

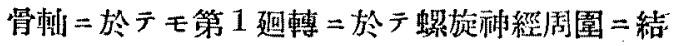
䋨織篔殖七儿外著戀ナシ。

前庭外淋巴慒及ビ牛規管外淋巴腔这二躰櫛及と 䥺斑ノ基質二八多數ノ赤血球及ビ多㤥白血球 ル外. 結䋨織細胞及ビ網狀織細胞, 增殖ガ認又 ラレ. 內淋巴腔 =八少數ノ組織球性細胞アリテ 之等，細胞原形質二八同樣ナ几脂肪顆粒存在 z。

聽神經纎維八螖牛殼第 1 迴轉骨螺旋板內 $=$ 於テ 全ク崩馈シテ多數，脂肪顆柆 7 有スル組織球性 細胞出現七ル外八何レ，部位ニ於テモ變化 7 㑇. メズ。

而シテ第 1 迴轉骨螺谈板二於ケル變化ハ未ダ蠗 旋神經節二八波及七ズ．同節細胞二八第 12 號 二認メタルガ如キ脂肪顆粘习證明スル事能八 ズ。

螖牛嗀導水管八鼓室階開口部附近二於テ八多數 ，脂肪顆粘 7 有スル多㤥白血球. 組織球性細胞: 
ᄏ認メ．網狀織細胞增殖シ内骨膜二於テハ結縍

識ノ增殖フルモ佾ホヨグ其管腔ヨ殘セり。

非注入側 ニ八何等變化ナシ。

第15號海猽 (注入後 1 ケ月)

诘入側 外聽道, 膿性滲出物八表皮, 破壤二 ヨリテ一部組織化七ラレ篇メ二外鳐道八狹クナ リ新生結締織細胞二脂肪顆粒 7 認 其染色反應 八上記ノモノト全ク同一ナリ。鼓膜八固有愿， そ保有七ラレ中耳腔側＝於テハ之二接シ脂肪顆 粒フ有スル多核白血球，集橉アリテ其周圍二八 多數，脂肪顆粠細胞习認么。

中耳腔八殊 $=$ 鼓室上浻 $=$ 於亏結締織，增殖著 ク小樫骨八全ク結縍織＝埋レタリ。之等ノ結䌟 織細胞二八佮木脂肪顆粠フ有スルモノアレド第 16 號=比シテ甚ダ少ク. 殊二結締織繊維，分化 著シキ部位二於デ多ンドそア認メズ。中耳粘 膜下組織八結締織ノ增殖 $=コ$ リ肥厚シ. 幼弱 結締織細胞二脂肪顆粒 $フ$ 認 $又$ 時 $=$ 有線分裂像 是スルモノニ之ヨ認ム。粘膜下組織二於テ八向 ホ多核白血球，外. 甚ダ少數ナレド莗軸狀偏在. 性核 $尹$ 有スル圓形細胞 7 認

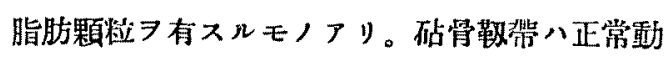
物 二於テ八脂肪顆垃 $=$ 於テ，其結縍織細胞，核，丽端 $=$ 脂肪顆粒 7 認ム。

鐙骨前庭關管八其中耳側八全ク新生結締織二埋 レ此部分二於テ八關節軟骨細胞，核八全ク「人 マトキシリン」染色セザルモ。㐻側二於デ

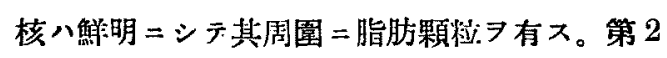
鼓膜ハ著シク肥厚シ多數，脂肪顆辢出現シ其結 締織八中耳腔側. 内耳貯側共二腔内二於ケル新 生結縞織二連りタリ。

螖牛殼第 1 呬轉鼓㖖階八全ク結締織ニョリテ充
サレ少數ノ赤血球及ビ縕䋨球性細胞习認ムルモ 多核白血球八殆ンドょヨ認メズ。脂肪顆粒モ極 メテ稀二存在スルノそナリ。コルチ器八此部位 二於テハ全ク 1 曆ノ骰子形上皮二筇化シ其原形 質二八染色上組織球二見ルト同一ナル脂肪顆拉

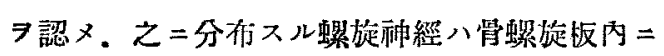
テ八全ク消失シテ結䋨織細胞及ビ組織球性細胞 之二代りタルモ脂肪顆䊀八極メデ少數=存在ス ルノ

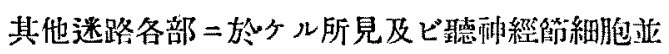

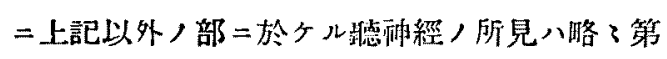
16 號二類セルモ組織化機轉八夫レョリモ高度= 進行セり。

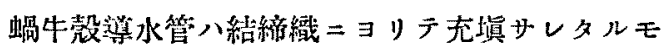
中二數個ノ小圓形管坹 $\ni$ 存シ恰モ血栓ノ眯通= 於ケルガ如キ狀 7 呈ス。此結䋨織二八脂肪顆独 フ認メズ。

非注入側 全ク異常习認メズ。 第13栫淮猽（注入媵 3 ケ月）

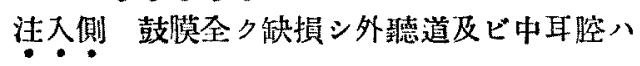
廣ク交通七り。中耳胞,骨壁ハ著シク肥厚シ䉆

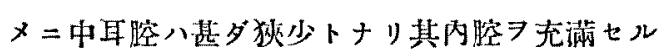
炎症性滲出細胞八略? 3 症二別夕ル。即于中央 二於テハ全ク融解シ「ズダン」ニヨリテー樣二淡 㗆赤色习是シ核，染色七ルモノナク其中二多數 ノ針狀結晶アリテ屡 : 菊花狀或八星芒狀二集合 シ分極光 $=ヨ リ テ$ 重屈折ヨ是スルモ熱スル時八

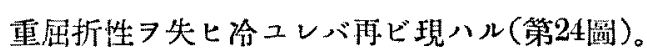
コロデッッ及ビ「デキトニン仮應陽性ナリ。カ カ儿壤死部，堆園二於テ八占木核，染色性保有 ヒラレ且ッ原形質二脂肪顆垃 ヨ認よ。最外側二 八脂肪顆粒細胞多數=存在ス儿外向木遊離，脂 肪㒀アリテ「ズダン」ニテ带赤色.「=イルブラ 
ウ」=テ紫紅色 7 呈シ單屈折性ニシテスそス・デ イトリーヒ. フイッシュレル. 濑川/各法及ビ 「ノトラルロート」㓌性ナリ。中耳粘膜入大 部分 $=$ 於テ圆柱上皮細胞二變化七ルモ蝸牛殼， 外側ノ部位二於テ八台木上皮, 再生完成セズ. 此部位 =於テ八組織球性細胞. 及ビ幼弱ナル結 締織細胞 7 認メ其原形質二脂肪顆粒存在七り。

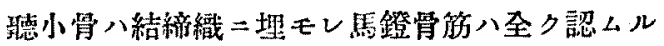

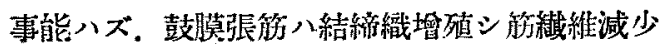
七ル外多数ノ脂肪細胞出現シ(第11践)。其染色 上ノ性質八露二「アトキシール」中毒游猽＝見タ ルモノト全ク同一ナリ(第 2 報告茢照). 副氏管 軟骨ハ消失シ其形態习留メザルモ正常動物二於

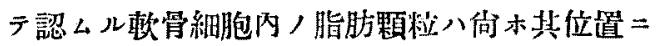
殘存シ染色反隹ニモ變化 骨性迷路素八所々二於テ吸收七ラレ其缺損部八

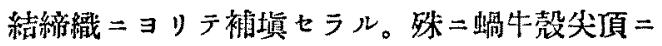
於テハ全ク骨壁习缺如シ結滴織八深ク螖牛內二

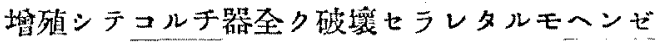

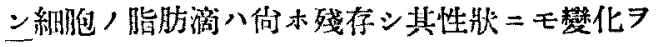
認メズ。蝸牛款第 1 迴轉二於デハ鼓室道八全ク 結縞織及ビ骨組織ニヨリテ充サレコルチ器ハ1 居，骰子形上皮細胞トナレルモ脂肪顆粒ハ之レ ヨ認メズ。骨螺旋板モ破壞セラレ螺旋神經節中 二結綗織，堆殖 七ルモノアレド細胞周圍二間隙フ認メズ又原形

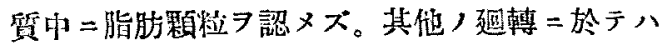
コルチ器稍、虚平トナリ有毛緭胞消失セルモ. ヘンゼン細胞ノ脂肪ニ八全ク變化ナク且ツ其他 何等異裳/脂肪物質ノ出現

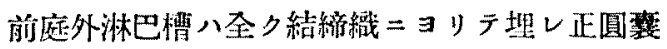

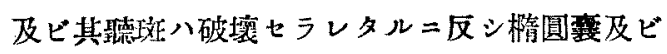

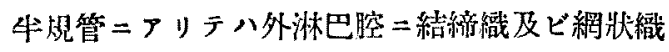

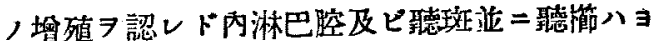
ク保存セラレ何等異常”脂肪沈着习證明セズ。 㯖神經組織八上記以外，部位＝於テモ結䋨緎，

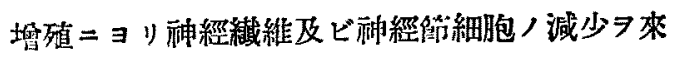
七共神經節細胞內二脂肪顆粘 $、$ 有スルモノナ シ。

蝸牛殼毹水管八網狀織細胞曾殖シ其核 =接シテ 脂肪顆粒ア有スルモノアリ。

\section{（2）細菌性炎症二於ケル所見}

第23號海猽（注入後 3 時間）

注人側 外㯖海＝八少量，多核白血球. 赤血

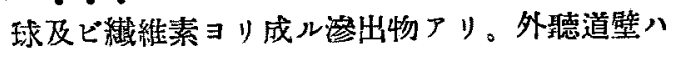
血管努倨シ時二內腔二赤血球及ビ脂肪滴习認么 ルノミナラズ所々二赤血球，澄出. 多核白血球

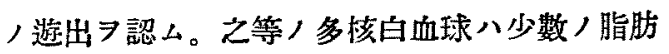
顆粒 $尹$ 有スルモ，アリ其性質及ビ血管內脂肪滴 ，性質八「ロ、フォルム」注入 =ョリテ出現七 ルモ，ト全ク同一ナリ。鼓膜八牚刺部以外二於 テモ表皮及ビ固有展ヨリ㸚離舉上シ水炧形成卜 認んべキ處アリ。

中耳腔=八少量，緎維素柝出シ多核白血球 7 混 ジ且ッ所タ二於テ出血习伴ヒタリ。中耳粘膜八 浮隀狀二腫脹シ血管著シク擴張，管腔內二赤血 球及ビ脂肪物睤 7 有シ粘膜下組織=モ出血及ビ 炎症性細胞涳出アリ。中耳胞骨壁中，血管=モ 脂肪物質ニヨリテ充渋セラレ「ズダン」ニヨリテ 赤染スルモノアリ。小聽骨筋二於テハ鼓膜張筇 腱部及ビ馬鐙骨筋，周園二出血アルモ脂肪染色 ニハ何等戀化ナシ。歐氏管. 小聽骨. 卵圓空二 モ異常ナっ第 2 鼓膜八其周緗部 $=$ 出血アルモ脂 肪染色上二八棪化 蝸牛殻 =於テ八鼓室階及ビ前庭階殊=下方趣轉

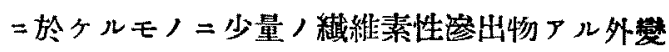


化ナク. 前庭二於テモ外淋巴槽二少量ノ㵶維素

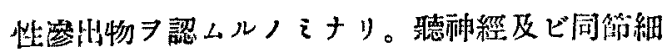
胞 $=モ$ 脂肪染色上何等變化 7 認メズ。

韭注入側 虱器八奎ク正常ナリ。 第21號游猽（注大後 6 時間）

注大側 外疆道及ビ鼓膜二於ケル所見八略? 第23號二同ジ。

中耳粘膜，睡脹八著シク塯加シ殊二上鼓室二於 テハ著明ノ出血アリ。砧骨靬帶及ビ前庭馬鐙骨 關節腔二八少數ノ多核白血球 7 認又其原形質二

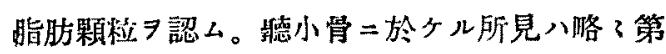
22 號=同ジ。

蜗牛殼外淋巴腔及ビ前庭外淋巴槽二繊維素性 H物ヨ認ムル事モ第23號ト同樣ナレドとヨリ强 度ナリ。

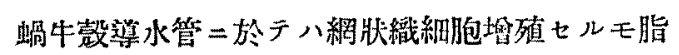
肪染色上ニ八變化ナシ。

非往入侧 全ク異常フ認メズ。 第25號晒猽 (注入後 12 時閐)

中耳膑，繊維素性滲出物二八多數，多核白血

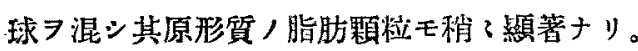
中耳粘膜浮腫狀二腫脹シ粘膜下組織二多核白血 球, 遊出 7 認么。

小㯖骨筋及ビ勒帶二於ケル脂肪染色ノ狀況八正 常二於ケルモノ二同ジ。

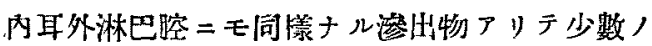
多核白血球 7 混 淇原形質二脂肪顆粠 7 認ムル モ內淋巴腔ニ八全ク異常ナク瑵神經及ビ同行細 胞，脂肪染色上，性質二モ戀化

非注入則 全ク正学ナリ。 第24碞海猽 (洼入後 24 時閒)

中耳腔／渗出物著シク膿性トナリ遊出七ル 多核白血球八多数，脂肪顆粒 7 有シ其性質八
「クロ、フォルム」注入二因リテ师現せルモノト 全ク同一ナリ。中耳粘膜，腫脹モ滈底トナリ著 明 /多核白血球ノ浸潤アル外多数ノ幼弱結締織

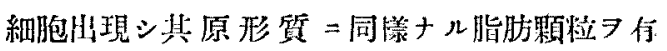

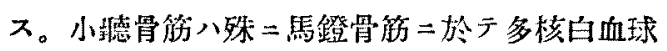

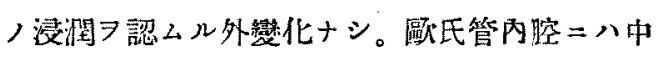
耳腟ニ於ケルト同㨾多核白抯球

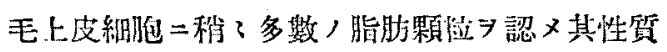
八多核白血球二於ケル气八ト同樣ナリ。

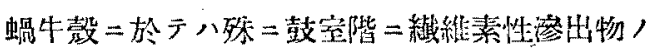
外秒 了多数ノ多核白血球及ビ少数 組織球性細 胞 7 認メ其等，原形質二八同㨾二脂肪顆怡存在 セリ。螖牛管及ビコルチ器二八等化ナシ。前庭 湎域二於テモ外淋巴腔至ル所二㵶維素及ビ多核 白血球

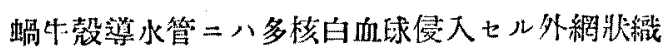
細胞及ビ結締織細胞, 增殖 ニ八同愫二脂肪顆船き認ム。

牙㯖神經及ビ同艒細胞二八何等變化ナシ。

非洼入側 至ク異常ヨ認メズ。 第27號湉港（注入後2日）

洁入側 鼓膜ハ著シク破壤七ラレ外聼道二モ

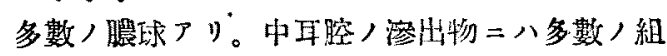
織的性細胞 7 認 $\times$ 其原形質内 $=$ 多數，脂肪顆糕

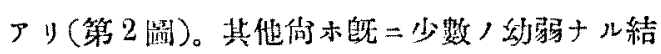

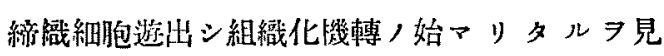
ル。斯ル細胞二モ「クロ、フ*ルム」外寭道注入

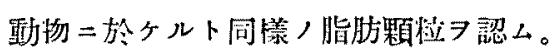

炎症八卵圆悹及ビ正圆悹二波及シ。鐙骨前庭阙 䠉腔內 =多核白血球 7 認 $\times$ 其軟骨細胞二多數，

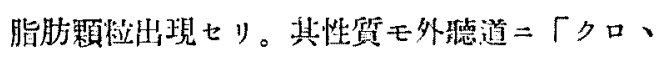
フォルム」ヨ注入七ル微物ニ於ケルト闹一ナリ。 第 2 鼓膜八結締織，䔣殖ニヨリテ秒 $、$ 肥厚シ多 
數ノ脂肪顆粘方認ム。

內耳及ビ神經組織二於分几所胃八略、第 24 號

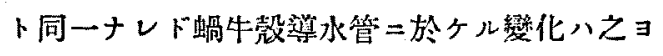
リモ稍 輕成ナリ。

非注入側 全ク變化 7 認メズ。 第26號海猽 (洼入後5日)

注入側 鼓膜及ビ中耳二於ヶル所胃八略、第

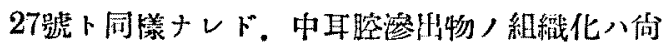
ホー層旺盛ニシテ多数，組織球性細胞及ビ幼弱 ナル結䋨織細胞 7 認 $\times$ 殊二組織球性細胞八多核 白血球ノ集圄 7 圍繞スルガ如ク排列シ其外側 = 幼弱結䋉織 7 認ムルヨ常トシ. 其脂肪八中性脂 肪卜看做スペキモ/比较的多シ。

中耳粘膜八著シク肥厚シ多核白血球, 外少数， 淋巴細杷及ビ車彻狀偏在性核フ有スル小圆形組 胞 モノアレド淋巴球ニハえヨ證明セズ。

蝸牛㯏ニ於テハライスネル膜著シク舉上シ第 1 超轉二於テハコルチ器全ク破壤セラレ骨螦旋板 内二於テ螺旋则桱，斷絴 庭兩階二八多數ノ炎应性渗出細胞アリテ結䋨織 細胞ノ新生 7 認ムルモ。渦叶管二於テ八第 1 迴 轉ノ外八著礔ナクコル千器モヨ゙ク保右セラレタ り(第 13 圆)。

前庭及ビ牛規管二於テハ外淋巴腔二多核白血球 及ビ組織球性細胞厂リテ網狀職細胞ノ增殖

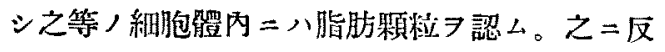
シ內淋巴腔及ビ神轱終末器官ニ八僖化ナシ。 聽神經八一般二其周園 = 圆形細狍, 浸洞. 結締 織細胞ノ管殖 螺旋神經，㫁絕习來セり。之等，部位二於テハ

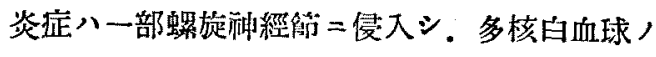

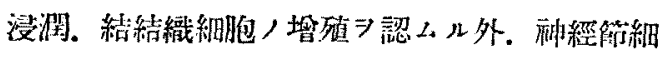

胞二核ノ萎縮或ハ膨化 躆淮猽二於テ認メタルト同樣，脂肪顆粒出現七 リ(第 22 圖參照)。

螖牛殼導水管二八多数ノ多核白血球. 組織球性

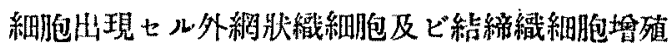
シテ管腔 $ヨ$ 門塞シ. 前者二八多量，後者二八少

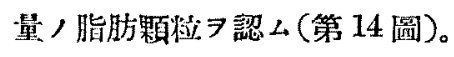

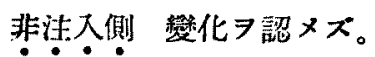
第31號活猽 (注入後7日)

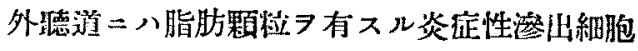
充满シ鼓膜八僅カ二固有居, 耳腔ニ於テハ遪出物，組織化機轉旺盛ニシテ多

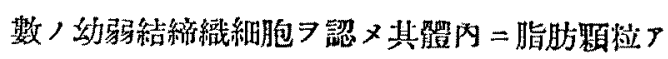
リ。歐氏管上皮細胞二モ稍 現ス(第 9 圖)。

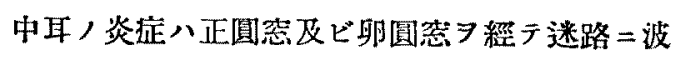
及シ㽞牛殸二於テ八鼓室. 前庭兩階二多數 ノ多 核白血球及ビ組織球性細胞アル外其被㠅屏ヨリ 多數, 絬䋨織細胞新生シテ腔內二遊出スルラ認 メ之等，細胞體二モ脂肪顆粠存在セり。螖牛管 八第 1 趈轉二於テ少數ノ多核白血球 7 認么几外 ハ一般二清汿ニシテコルチ器モヨク保存セラレ

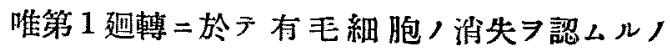
i。

前庭二於テハ外淋巴㥀 = H血及ビ白血球，游出

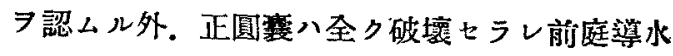
管二八多孉ノ多核白血球アリテ組織球性細胞二 捕食セラレタルモノフリ(第 23 睑)。

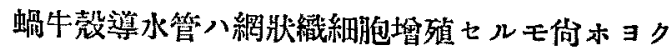
管腔ヨ存セり。

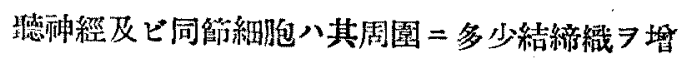
殖セルモ脂肪染色上二八慗化 非注入側 全っ絞化タ認メズ。 


\section{第22號海崦 (注入後 10 日)}

洁入側 鼓膜八殊二表皮ノ著シキ增殖二ヨリ テ甚ダ肥厚シ。且ッ內面八蜴牛豰卜癒着七リ。 中耳腔及ビ其粘膜二於ヶル所胃八略 、第 26 號 ト同一ナルも中耳胞内骨膜ヨリ著明ノ骨新生 來シ中耳腔ハ喇小トナリ新生七ル圆柱上皮細胞 ニ八多数, 脂肪顆粒》認ム。

第 2 鼓膜八著シク肥厚シテ炎症内耳二侵入ス

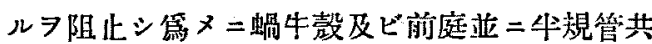
=外淋巴膑二八瀻維素及ビ少數，多楮白血球 7 認ムルモ內淋巴腔＝八何等渗出物ナク．神經終 末器官正常 ニシテ神經組織ニモ變化フ認メズ。

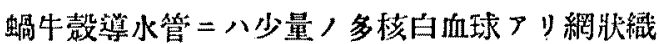
細胞輕度二箸殖七リ。

非洁入例 全ク異常ヨ認メズ。 第33躆㴬猽 (浙入後10日)

本例八炎应極入テ激苴ニシテ鼓膜及ビ中耳粘 膜八全ク壞死二陷りテ「ズダン」ニョリテ然㩐造 二淡带色 7 呈シ。核川「へアトキシリン」きヨリ テ染色セラレズ。歐氏管モ全クカ、ル壇死組織 二圍マレ軟骨細胞ノ核ハ「へマトキシリン」ニ染

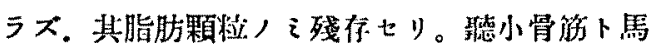
鐙骨筇川全ク破壤七ラレタルモ鼓谟張䈃八殘存 シ結縞織ノ垻殖 7 來シ結締織細胞, 核, 兩端二 八脂肪顆粒 認么。

第 2 鼓膜及ビ馬鐙骨足板モ全ク壇死二陷り炎位: 八内耳 $=$ 侵入シ螎牛殼第 1 及ビ第 2 廻轉二於テ

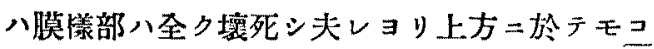
ルチ器八全ク破壞消失シ。鼓室階八全部。前庭 階モ大部分結䋨織＝埋レ其間ニ多数，大ナル脂 肪顆粠細胞习認么(第 16 圖)。螖牛管ハえレ= ヨリテ上上皮細胞二圍マレタル嫰少ナル管腔二變

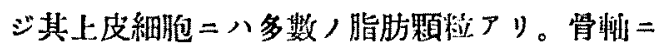

於テハ血管內腔及ビ內被細胞二脂肪物質 $フ$ 認

且ツ周图二脂肪顆粒細胞集合七り。

而シテ分極光ニテ檢スル時ハ之等中耳及ビ內耳 八壞死部二八多數, 重屈折性企狀結晶习認メ。 加温スル時八重屈折性 7 失ヒ冷ュレバ再ビ甘!現 ス。ジロデっツ及ビ「デギトニン」反應陽性ナ り(第 24 沺參照)。

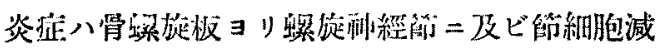
少シ.殘存七ルモノモ䨞了核ノ萎縮及八膨化 來シ．原形贸二多數，脂肪顆䏠习有ス。從テ蝸

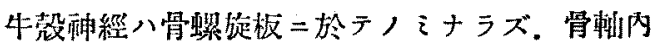

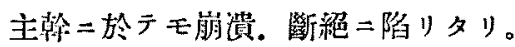
前庭領域二於テモ炎提八外淋巴腔ノミナラズ.

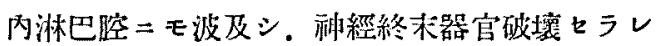
結締織, 增殖 7 認么ル外多數, 脂肪顆拉細胞出 現七り。前庭种經八其周圍二結締織，增殖 シ。命縕胞戀性シテ脂肪顆粠フ存スルモアアリ (第 21 圆)。

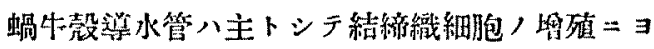
リテ開塞シ. 前庭導水管及ビ內淋巴管 ニ八多數 ノ多核白血球出現シ組織球性細胞二捕食七ラレ タルモノアリ。

非洁人側 聽器ハ全ク正常ナリ。 第35啹谁猽 (注入後 15 日)

清入側 鼓膜及ビ中耳=於ヶル所見八略、第 33 號卜同漛ナルモ中耳腔ニ於ケル炎症ハソレヨ

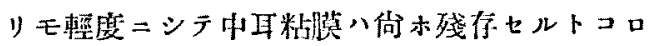

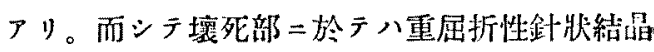
ヨ見儿事第 33 號卜同恗ナレド殘存部二於テ八 結締織ノ墦殖及ビ中耳胞骨壁ノ吸收习認ム。鼓

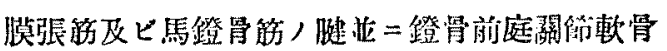
細胞二八多數ノ脂肪顆接出现七り。

炎定八第 2 鼓点及ビ卵圆空 


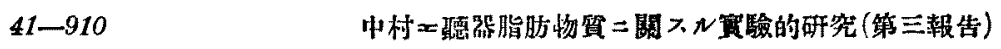

ルモ迷路/綎化ハ第 33 號ヨリモ輕度ニシテ組 織ノ壤死

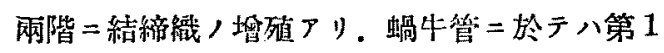
迴轉ニテ八多数，多核白血球アリ。 ライスネル

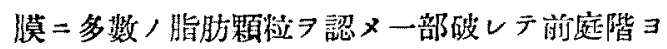
リ結䋨織細胞ノ侵入七ルヨ認ム。コルチ器八其 形態习存スルモ有毛細胞消失シ.且\%多數/脂肪 顆糧出現七リ。其性留八多核白血球或八結縍織 細胞二認メタルモノト同一ナリ(第 15 圆)。 前庭項域二於タ几變化モ第 33 號ヨリハ輕度二

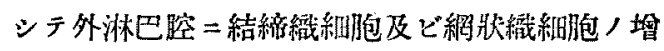
殖アルモ內淋巴膑ニ八少數，炎掟性渗出細胞ア

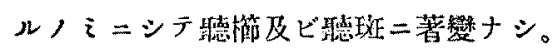

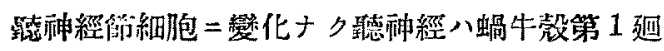

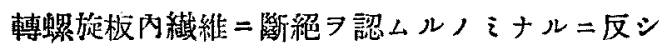
類面神經八其周園二結楴織，增殖 來シ多數，

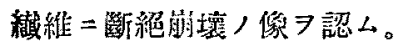

螖牛殼等水管及ビ內淋巴管, 所見，第 33 號卜 略 ?同一ナリ。

非注入側 全ク絞化 7 認メズ。 第36號皅港（注入後20日)

让入側 鼓膜八全》缺損シ中耳腔二ハ多量， 膘汁アリ。上鼓室二於テハ組織化著シク小躵骨 八全ク結綃織ニ埋レタルモ中耳貯，下部二於テ

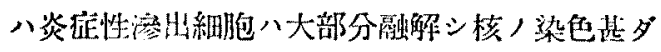
不良トナリ多数ノ重屈折性針狀結晶出現七り。 外聽道及ビ中䛌，骨壁=於テ八骨，吸收及ビ 新生㕵盛ニシテ骨慔細胞二脂肪顆粩 7 認ムルモ 破骨細胞ニハ之フ認メズ。中耳粘膜下組織二於 ケル新生結緕織細胞八渗出物，組織化機轉尚木 完成セズ上皮ノ再生

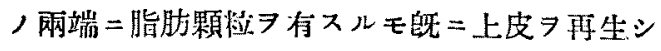

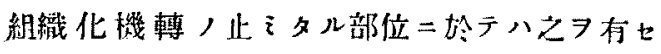

ズ。小聽骨筋及ビ歐氏管八破壤セラレ全ク其形

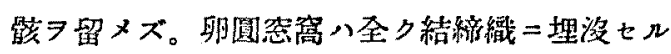
モヨク炎扯ノ迷路二侵入スル事习阻止セリ。馬 塩骨前庭關節軟骨細胞二八多數/脂肪顆煌出现 ス。第 2 鼓莫ハ著シク肥厚シ其結縍縚細胞八多 數ノ脂肪顆糊习有シ且ツ中耳腔及ビ鼓室階ヨ充

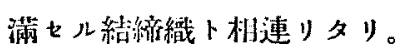

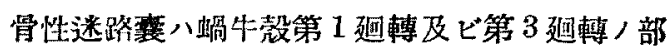
及ビ水平牛規管，部二於テ破塤七ラレ第 1 迴轉 鼓宔階及ビ第 3 画䡜前庭階入全ク結䌟織=ヨリ テ充垻セラル。其他/部分二於テ八螖牛管二赤 响球 7 認メライスネル膜擧上七リ。コルチ器” 第 1 迴轉及ビ第 3 趈轉二於テ有毛細胞破壤七ラ レタル外ハ一般 $=ヨ$ ク保存セラレ蝶旋神經及ビ 同解細胞二異常ナシ。

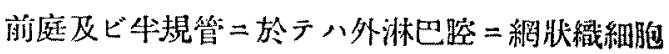

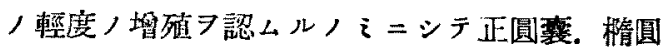

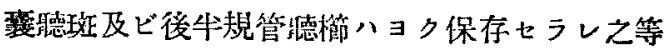
人神經㵶維. 同節細胞二モ何等紫常ナク只水平

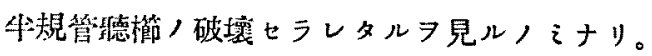

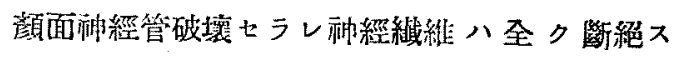

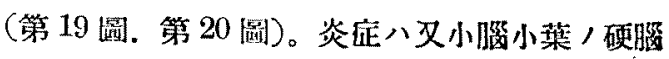
膜下 $=$ 及ビ內骨膜肥厚シ結䅸織細胞=脂肪顆粒 习認么。

韭讨入側 全り異常タ認メズ。

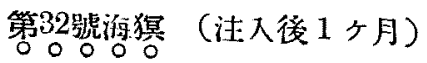

鼓膜八著シク肥厚シ腤部二於テ第孔ス。中耳 腔二八多量ノ炎怔性渗出緗胞アルモ融解二陷レ ルモノナク．組織化機轉八極メテ忹盛ニシテ多 數ノ紐織球性細胞及ビ必弱結䋨織細胞 7 認 $又$ 其

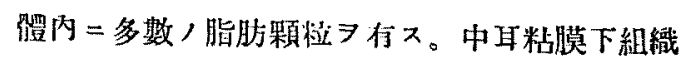

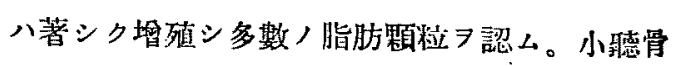

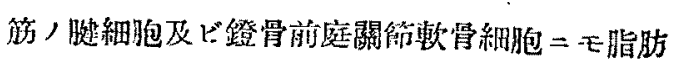


顆棓出現セり(第 8 滑)。

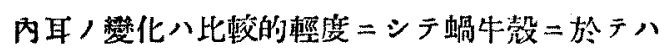

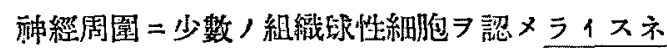
ル膜稍?舉上七ル外著禁ナク．前庭二於テモ外 淋巴槽二少數, 炎症性涳蛙細胞习認ムルノそナ リ。聽神經. 同愁細胞二小全り變化 7 認メズ。

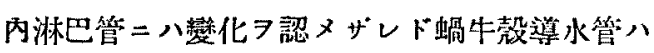
網狀織細胞ノ增殖ニヨリテ甚ダ诙陸トナレリ。

非洼、側 全ク䌁化ア認メズ。

第39號晒猽（法入後 2 月月）

洼入側 中耳粘膜八著シク肥厚シ中耳胞骨壁

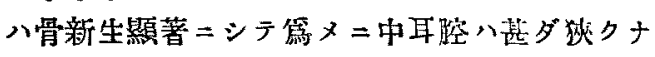
リ粘膜上皮細胞八圓柱狀トナレリ。之等ノ部位 ニ於テハ最早脂肪顆料ヨ認メズ。小聽骨筋八全 ク結縍織二埋レテ鼓膜張筋内二八多敖ノ脂肪紬 胞出現七り。歐氏管軟骨ハ一部消止七ルモ軟骨

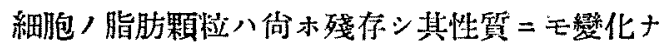
シ(第 10 矛參照)。

卵圆壳八全ク結䋨織二坜レタルモ炎症ハ此部二 於テ阻止セラレ內耳二侵入七ズ。之=反シ第 2 鼓膜八全り消失シ此部＝於テハ鼓室階ノ中耳腔 トガー樣二新生結樀織ニヨリテ充堛セラレ多數

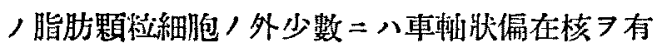
スル圓形細胞ニシテ脂肪頼䊀フ有スルモノラ認 么。

螖牛殻第 1 呬轉二於テ八鼓室階八全ク結締織 = ヨリテ充サレタルノ $゙$ ナラズ骨新生アリテコル 手器八倘木其形態习存スルモ有毛細胞八消失七 リ(第 18 圖)。其他，部位二於テ八鼓室．前庭 兩階ニ少量ノ結䅧織 フ新生セル部アリ殊二尖項 二於テハ骨性迷路淢，缺損アリテ結䋨織 テ補填セラレタルモ螖牛管二八變化ヨ認メズ。

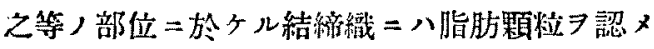

ス。前庭领域 =於テモ外淋巴慒二少量，結締䄉 ヨ新生七ル外著戀ナシ。

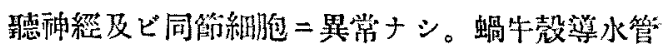

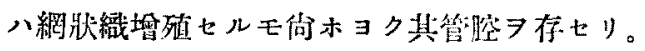

非洼大側 中耳粘膜肥厚シ婪二㰧氏管閒口部

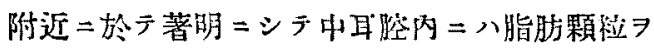
有スル多核白血球及ビ組織球性和胞フ認ムルモ 内耳及ビ外耳ニ八㱍化 7 認メズ。

\section{第41號诲猽 (注入後 3 ケ月牛)}

注入側 中耳腔内 =於ケル炎证性洷出物，縕 織化㙨轉”佮木忹盛ニシテ多數，組織球性細胞

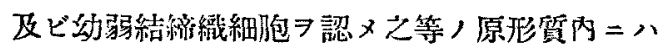
多數八脂肪顆柆存在ス。中耳胞骨壁八骨，新生 ニョリテ著シク肥厚セル外，中耳粘膜下組織モ 增殖シけ耳腔规小トナレリ。粘膜上皮細胞八再

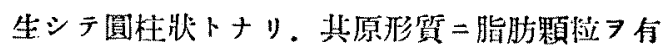
スルモノリリ

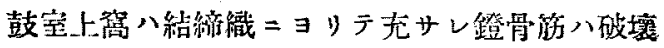

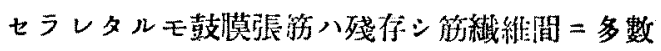
ノ脂肪細胞認么。

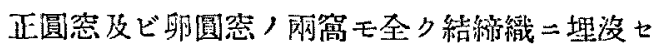
ルモヨク炎掟，進行 $习$ 阻止シ (第 12 圖)。カ、 ル部位二於テ八最早結稳織細胞二八殆ンド脂肪 顆粒

內田ニ於テ八前庭外淋巴槽二少量，結維幟 7 新

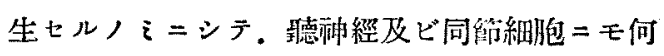
等紗化フ認メズ。

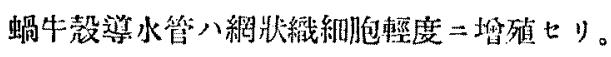

韭注入側 全ク䇣化ヨ認メズ。

\section{凹. 總括立业二考䓩}

以上, 所胃 7 通覽スルニ「クロ、フォルム」外

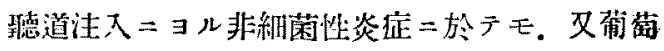




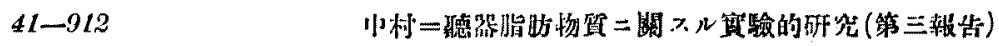

缺球菌浮游湤, 中耳腔注入 $=$ ル細菌性炎症二

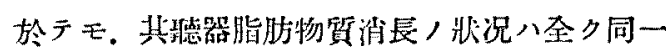
ナルラ以テ便宜上兩著 ヘントス。

炎怔ノ初期二於テ注意スべキハ，毛細血管二於 ケル脂肪物質ノ集積ナリトス。此脂肪物質八染 色反雇上脄義「リポイド」及ビ中性脂肪卜認ムべ キモノニシテ. 甚ダシキ時八全ク血管內ヨ无雨 シ恰モ血管內色素注入標本 $ヨ$ 見ルガ如シ（第17

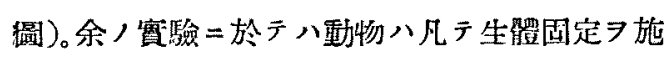
シタルモノニシテ. 且ッ健側二於テハ決シテカ カル物質フ認メザリシ事ヨリ考フレパ. 此脂肪 物質八血厅゙

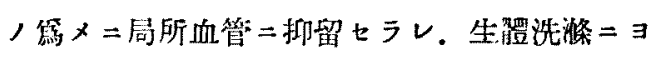
リテモ流レ去ラザリシモノト解スベキモノナ y。

次デ外德通. 中耳腔或八迷路內二嘼浓性或八繊 維素性，渗出物玩ハレ。組織內及ビ腔內 $=$ 炎症 性洷出緗胞, 游出 7 認山(第 1 圖)。其細胞八炎 症/初期二於テハ殆ンド全ク多核白血球ノ $i=$

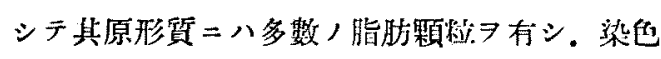
反鷹上ヨリ言へバ主トシテ狄笔「リボィド」ニー 致スルモ，份示中性脂肪卜認么パキモ，モ存 在七リ。

そニ續イテ游叫大ル八組織球性細胞ニシテ同情

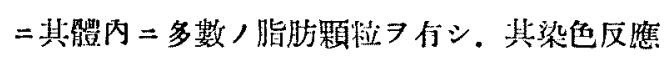
モ多核白血球二於ケルト同情ナレド、炎症古 クナリシモノニ於テ八中性脂肪卜認ムべキモ，

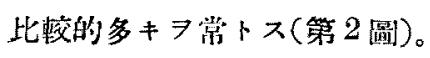

以上ノ外「プラスマ」細胞卜認ムベキモノ=モ同

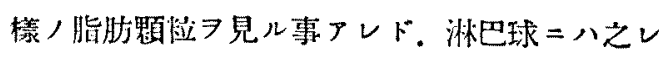
ヨ證明スル事能ハザリシハチャチォ(1)，炎症性 滲出細胞二於分儿脂肪物質檢索成績ニヨク一致
セリ。

炎征性機轉稍、進行スル時八組織中二於ケル結

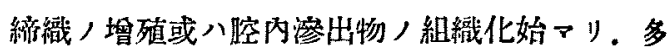
數ノ幼弱結縍織細胞出現ス。斯ル時期 =於テハ 新坐結綡織細胞川原形質二脂肪顆柆 $习$ 有シ。其 量多キ時八細胞體内二立滿スルモ少キ時八核 兩側二接シテ存在スルラ常トス（第 3 圖及ビ第 4 圆)。染色上八性質 $コ$ 言へバ此脂肪物質八主 トシテ狹皒「リポイド」屬スルモノナレド问本 中性脂肪卜看做スバキモノモ存セリ。

而シテ組織化ノ僬行スル所二於テ八組織球性細 胞密集シテ出出物，清泊河七。其原形質二八 極メテ多數ノ脂肪顆粒つリテ。所謂脂肪顆粒細

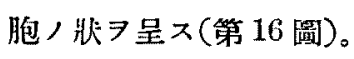

興味アルハカ、ル結䋨織細胞，脂肪顆柆ガ組織 化，任盛二行ハレッ、アル場所二於テハ多量= 存在スルモ。之ヨ離ル、二從テ減少シ。結䋨織 增殖八完了七ル場所二於テハ之

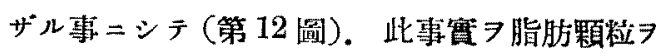
有スル絬縞織細胞, 核ノ染色狀態及ビ形態二们 等巽常ナク．原形留モ其他ノ爿况全ク正常ナル

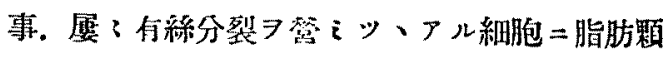

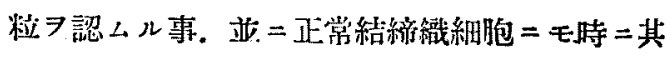
核ノ兩端二脂肪顆䊀乡有スルモノアル事。等卜

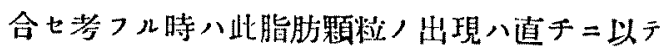
退行性嶈化ナリト看做ス事能ハズ。等口却デ結 締織ノ垻殖二關係习有スル旺盛ナル進行性㙨轉 ト認ムベキモノアルラ覺ュ。

炎症激烈ニシテ組織壞死二陷り，或八炎症性㦄 出細胞, 吸收又心組織化行ハレズシテ融解七ル 場合二八其病福二多數ノ針狀結晶 7 認 $\times$. 重用 折 7 是入 (第 24 副)。其理學的及ビ顕溦化學的 ，性質八全ク「コレステリン」ニ一致セリ。 
之等ノ變化ハ何レモ聽器各部 $=$ 於テ共通 $=$ 見ラ

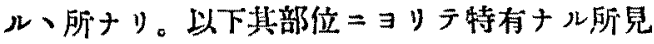
フ述プベシ。

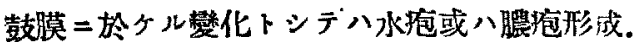

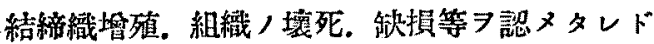
其際二於々ル脂肪染色的所見八上記一般的記載 こ求キ、放テ特記スべキ事ナシ。

中耳粘膜八圆柱上皮細胞トシテ再生スル事多

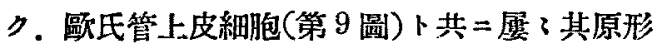
質=脂肪顆粞 7 有 中性脂肪。一部八狄㼁・リボイド」ト看做スべキ モノナリ

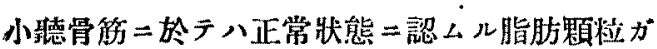
洼二減少或八消失スルモノアル外，長時日生存 七儿動物二於テ八鼓膜張緼內二多數 /脂肪細胞 出現スルラ見タリ(第 11 圖)。カ、ル脂肪細胞

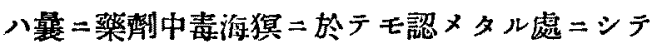
機能廢絕=ヨル二次的變化ナリト解シタルが(13) 今回ハ更二一愿高度二發現七リ。即チ本實駿二 於テハ迷路 =於ケル炎症性禁化，外 $=$ 中耳 $=$ 於 テモ著シキ結䋨織，增殖アリ，小聼骨が全り之 二埋レタル事焦ミナレバ. 其機能虔絕モョリ高 度ナルモノア期待シ得べキナリ。

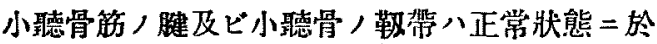
テハ脂肪物啠フ有七ザレド(12).中耳，炎症二伴 七テ其細胞恔ノ爾端二多數ノ主トシテ狄䉝「リ ボイド」=一致スル脂肪顆愔出現七り(第6圖)。

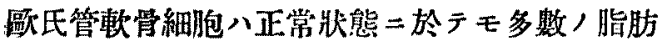
滴 7 有スルモノナルガ(第 9 圖參照)此脂肪滴八 炎症ニョリテ軟骨破壤七ラレ。其㤥モ「へマト キシリン」二染色セザルニ至リテモ倘ホ長ク其 位置二殘存シ染色上，性質二モ禁化ア來ザ、ル 事アリ(第 10 㘣)。

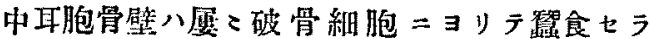
レ. 刃一方二於テ八類著ナル骨新生フ來シタル ガ此際破骨細胞ニ八脂肪顆粒 シ。造骨細胞二八多數,脂肪顆愔フ認メタルハ 興味アリ。其性贸ハ主トシテ狄军「リポイド」ナ リ。

资症卵圆悹及八正圆悹二波及スル時八之等，部 位 =モ脂肪顆䊀，出現 7 認么。郎千鐙骨前庭關 笷軟骨二於テハ正常狀態ニテハ脂肪顆粒ヨ認メ ザル二不拘(第 7 圆). 炎症, 波及二ヨリテ軟骨 細胞二脂肪顆盖，現儿、ヨ見儿(第 8 圖)。其染 色上八性質八狄㼁「リポイド」二一致ス。第 2 鼓 暯二於テモ同漛ニシテ. 炎症 /波及 $=ヨ$ リ其結 縍織細胞ノ核, 爾端=多數,脂肪顆粘出現スル モ。炎症終息スル時八再ビ消失ス(第 12 圖)。䒚 關係一般結縍織細胞二於ケルト同阥ニシテ其染 色上ノ性質モ之ト同一ナリ。

螖牛殼ニ於テハコルチ器支柱細枹. ライスネル 膜. 蚡旋靯氿結締織細胞二脂肪顆煜 $/$ 沈着 7 認 メタリ(第 15 舒)。其染色上八性質八一部八中 性脂肪二，一部八诙義「リポイト」二一致ス。 鼓室. 前庭网階及ビ蝸牛管二於ケル炎症性滲笑 細胞二見ラル、脂肪顆粒及ビ其組織化機轉二件 ヒテ出現スル脂肪顆䊀，爿况及ビ其染色上ノ性 質八上記一般的記载二述ベタルトコロ二全ク一 致ス(第 13 圖，第 15 圖，第 16 圖，第 18 圖)。 正常拰猽二於テ認メラル、ヘンゼン細胞，脂肪

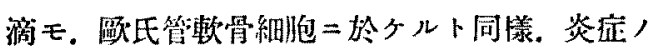
繁來习受ケタ儿場合ニアリテモ。比較的長ク其 位置二殘存スル事アリ。

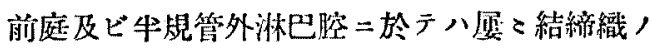
外二網狀織細胞,增殖 7 認又淇原形質二モ同㨾 二脂肪顆棌 認ム。 


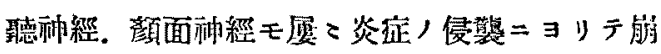
潰䌎絶ス。其脂肪染色上ノ所見八「アトキシー ル」中毒ニ於テ兒タルト同管ニシデ(13). 反應八 狄峩「リボイド」ヨリ渐㳄二中性脂肪二移行ス。 唯「アトキシール」中毒=菈テハ神經瀻維，部位 ニョリラ崩啮機轉ノ程度が種々ナリシ =不拘。

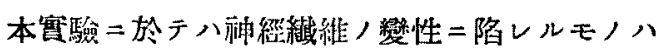
單二末梅部，破壤セラレタルモノヨ除キテへ。 各部位二於テ同一程度，崩湝牀態 7 示七リ。 （第 19 圖.第 20 圆)。而シテカ、儿場合八凡テ神

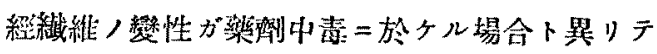

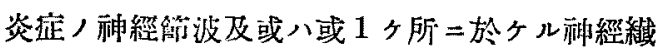
維ノ破壞二因ル二次的戀性二外ナラザル事 7 思 へバ此差異八誠二常然ナリト言つベシ。 神經節細包八余，最モ注意セルモノ、1ナリ。

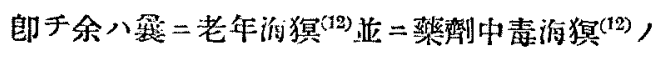

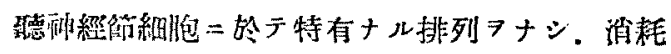
性含脂肪性色素顆柆 $=$ - 致スル脂肪染色反應 7

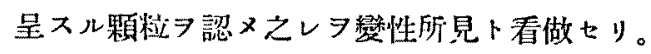
然ル二本實驗二於テ八上記實酸動協中 1 例二於 テモ之ヌ認メザリシノミナラズ. 特ニ之ガ检查 ，目的二作成七儿多数，蛹牛亮骨泏剔出標本 ${ }^{(12)}$ 二於テモ之ヨ認ムル事能ハザリキ。之二依テ見

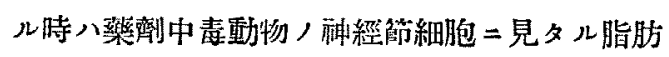
顆垃八葙劑ノ直接作用ニョルモノニシテ、神經

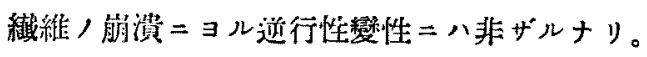

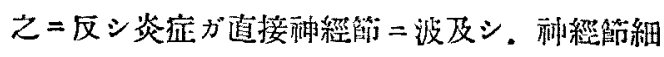
胞ガ炎症機轉 ニョリテ賃害七ラレ。原形質，境 界不明瞧トナリ。核ガ高度二莠縮シ或八膨化七 ルガ如キ細胞二於テ八. 上記ノモノト全ク别種 ノ脂肪顆糕ノ出現习認ム。即チ此場合ニアリテ

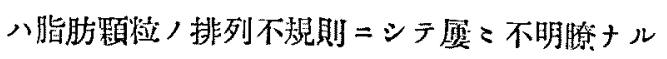
細包限界
ナルノネナラズ. 染色反應モ全っ机異りテ中性

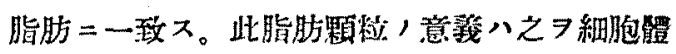
自身，甚ダ高度ナル学性所見ョリ考フル時八炎 症，直接作用 $=\Xi$ ル种經節細胞，前潰卜關係 有スルモノナルベシ。

韵庭導水管 $=$ 浸入七ル多核白血球八此處 $=$ 存在 スル特有ナル單核圆形細胞二捕食セラレ，其狀 答モ余，內耳脂肪物質注入實驗 ${ }^{(2)}=$ 於テ見タル $ト コ ロ=$ 相一致又(第 23 圖)。

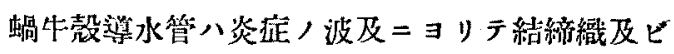
網狀織細胞ノ墦殖フ來シ甚ダシキ時二八全っ管 腔，閉塞 中 ${ }^{(20)}$ ）研究 =從へバ迷路炎，頭苗內進行 $\ni$ 防止 セントスル反應現象卜解スベキモノナり。

台ホ注意スべキ八斯/如キ蝸牛殼導水管，開塞 アル場合二八必ズライスネル膜/舉上フ認メタ ル事ナリトス（第 13 國)。其原因シ考察スルニ 先ヅ內. 外淋巴腙二於ヶル炎拝性渗出機轉 $=\exists$

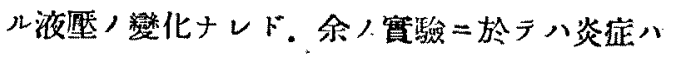
常二外淋巴腔二於テ内淋巴腔ョリ高度ナリシニ 不拘ライスネル膜，低下セルモノ八1例モナ

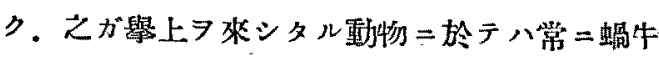
款導水管, 閏塞 $尹$ 認メタルハ此网所見，間 $=$ 關 係アリト看做スア安當トシ. 小田及ビ森 ${ }^{(15)} カ ゙$ 鵜 山，實驗成績 ${ }^{(23)}$ フ引用シ。迷路炎二於ヶルライ スネル膜，舉上八迷路水蕾ヨリモ螖牛殻導水管 閉塞ニヨル外淋巴液, 減少ニヨルモノナラント

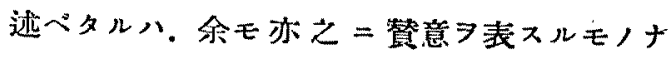
リ。

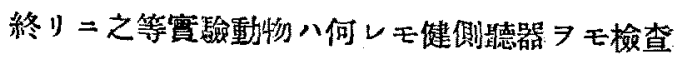

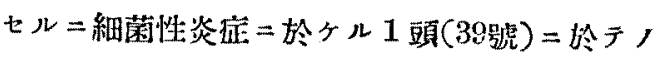

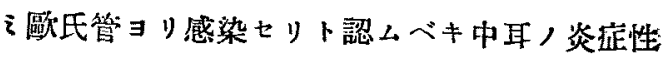
歀化 7 證明七几外八何等異常ナク其脂肪染色的 


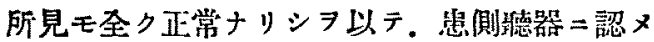
タル脂肪物質，出現八全っ局所的原因 $=\exists ル モ$ ノナル事ヨ知リ得タリ。

之ヨ要スルニ聽器，炎症性變化=件ヒテ其各部 二著明ノ脂肪沈着 7 認メタルハ注目二價スル處 シシテ．現今一般ノ見解二從へバ之等ノ脂肪物 質ハ血行ニヨリテ㯖器二到達七ルモノト認ムペ ク. 炎症 初期 =於テ血管內 =影著ナル脂肪物 質ノ集積习認メシハ之ニ一致七ルモノト言つベ シ。

一般=血行內二鐱入七ラレタル物入質八內耳二移 行シ難キ事八周知ノ事實ニシテ殊二生體染色= 關スル實驗 =於テ明ラカ二認メラル、所ナレド

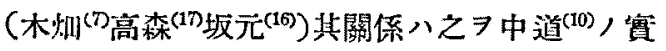
驗的研究 $=$ 徵スル=脂肪物質二就キテモ全ク同

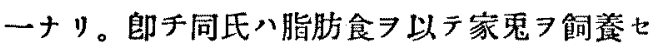
$ル=$.中耳 $=八$ 比較的容易二脂肪沈着 $\exists$ 乘 モ.内耳ニ八極メテ長時日飼養セル後初メテ出

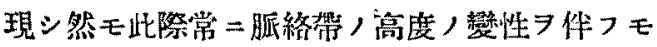
ノナレバ單ナル沈着ト八稍 $こ$ 其趣 7 異ニシ。血 管ノ紸性 而シテ余，實驗二於テ八何等特殊，食伹７與人 シモノ =非ザルヨ以テ，身䯣固有，脂肪物質ガ 炎㱏性變化 =伴ヒテ血管內二集積シ之ガ組織内 二移行セシモノト解スベキナリ。

之ト對照シテ甚ダ臖味アルハ.クスネッオスキ 二(8)八實驗ニシテ氏ハ結締織二炎症ヨ惹起七シ メタル家鬼，靜脈內二墨汁洼入七ル二炎症病 綮二於テ八血管內二墨，顆粒集積シ。遊出七ル 多數白血球，結䋨織細胞等二モ墨/顆粒 7 認又 シモ炎症病镇以外二於テハカ、ル所見 トナシト言へリ。更=同氏 ${ }^{(9)}$ 八家鬼 $=$ 脂肪食 7 與フルモアヒレス腱ニ八脂肪沈着フ認メザルニ
一度之=炎症习惹起セシムル時八容易二脂肪沈 着ヨ來スコトヨ報告セリ。之等，所見八余，算

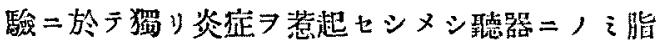
肪物質, 出现 7 認又。健侧二於テ八何等異常， 脂肪物質习認メザリシ事トヨク机一致七リ。 即于此脂肪物質八炎拝性戀化ニヨリテ血管 7 通 ジテ組織ニ移行セシモノニシテ．單一ナル塩器 ノ變性ニヨリテ八著シキ脂肪沈著习來サ・ル事 八余ハアトキシール」中毒游猽聽器二於ケル脂 肪物質, 研究 ${ }^{(13)}=ヨ$ リテ明ラカナリトス。此關

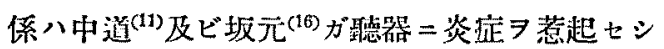
ムル時八正常狀態 =於テ陰性ナル內耳生體染色 ガ著明 =陽性トナルト述ベシ事ト相對照シ莡ダ 璵味アル處ナリ。

而シテ余，宦驗ニョリテ著明二脂肪顆拉，出現 フ認メタルハ多核白血球. 組䋨球性細胞. 絧跃 織細胞及ビ結締織細胞ナリ。然ルニ之等，細胞

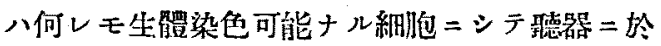
テモ全ク同一ナル事八上記諸家ノ呼究ニヨリテ 明ラカナルそナラズ. 余)實驗的研究 ${ }^{(14)}=\exists$ レバ之等ノ細胞八同情ナル機轉 ニョリテ聽器二 輸入七ラレタル脂肪物犋 ス。而シテ之等ノ細胞が屡?炎症,初期ヨリ著 明,脂肪顆椪ヨ有シ。然モ其核, 染色狀態及ビ

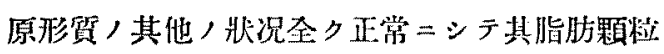
出現 7 以ラ直チ＝變性所見卜看做ス事能ハザル 場合少カラザルラ思へバ. 少クトモ之等，細胞 二出现スル脂肪顆粠，一部八貪检機轉或八生顝 染色卜同一機轉ニヨリラ細胞內二攝取七ラレシ モノニシテ必ズシモ退行戀性=ヨルモノニアラ ズ繁口却テ旺盛ナル生活現象/表現ト見ルベキ モノアリ。

就中結䋨織細狍二於ヶル脂肪顆粹ノ壮現が. 其 


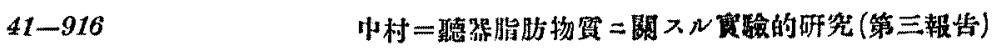

篔殖機轉ト密接ナル關係フリテ此感习深カラシ

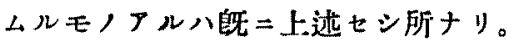

而シテ中耳腔及ビ歐氏管上皮細胞。鐙骨前庭關 節敦骨細胞. 小㯖骨筋腱細胞. 迷路內. 外淋巴腔 被稪細胞. コルチ器等二出現七ル脂肪顆粞ハ之 ト稍了趣 $コ$ 異ニシ所謂脂肪謷性トシテ理解シ得 ラル、モ．斯儿場合＝於テモ周圍ヨリノ脂肪物 質, 供給ト細胞ノ生活力トヨ必要トスル事八】 Aシュレル(4) $/$ 研究ニヨリテモ推测シ得ベシ。 郎チ同氏ガ腎梗塞二就キテ研究セルトコロニヨ レバ脂肪管性ハ必ズ血液又八組織液, 流通 7 存 シ細胞ガ生活力フ保有七ル部位ニ於デミ認メ ラレ. 血流全ク杜絕七ル場合. 又八細胞カ死隇 セル場合八脂肪沈着习認ムル事能ハズト云フ。 之二反シ激烈ナル炎症 $=ヨ$ リ組織が壇死二陷り タル場合. 又八咨祉性济出細胞方融解七儿場合 二刿現スル多量ハ「レステリン」ハディトリ。 ヒ $^{(2)}$ 及ビ川村 ${ }^{(6)}$, 言へルガ如ク細胞, 死隇 $=\exists$ リテ遊離セシモノナルベシ。

\section{結論}

1. 福器. 殊二内耳八脂肪沈着
織ナル二不拘. 之二炎症ノ登來スル際二八他組

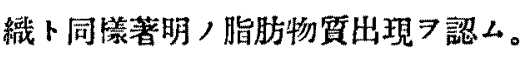

2. 此脂肪物質，出現狀况八細菌性炎症 $=$ 於 テモ．非細菌性炎庭＝於テモ全ク同ーナリ。

3. 此脂肪物貿, 出現八退行数性 7 以其全 部习說明スル事能ハズ. 少クトモ其一部八炎定 刺战二對スル旺盛ナル反應機轉卜解スペキモ， ナリ。

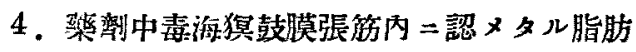
細胞八，中耳炎及ビ迷路炎习有スル海猽二於テ 八更二顯著二世現ス。

5. 藥劑中毒 $=ヨ$ 几海猽コル千器）戀性 $=$ 於 テハ脂肪物質，出現 ニョル玟性ニ於テハ之ガ出現フ認ム。

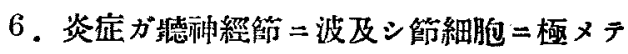
高度，性 $\ni$ 來七几時八其原形質 $=$ 脂肪顆粒出 現ス。

7. 此聽神經節細胞內脂肪顆愔八老龄海猽及 ビ䒚劑中毒缏猽二認メシモノト其排列ノ狀況及 ビ脂肪染色上ノ性質 7 異 $=$ *. 全然别個/性質 ノモタリ。

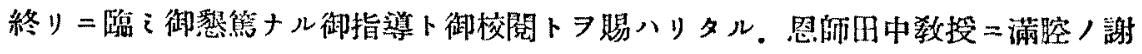

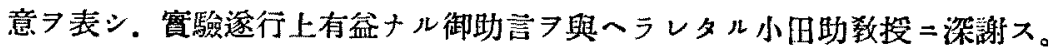

\section{文}

1) Ciacio: Über das Vorkommen von Lecithin in d. zellul. Entzaendungsproduct. Zent. f. a. P. u. p. Anat. bd. 20. 2) Dietrich: Stoerungen d. zellul. Fettstoffwechsels. Ergebnisse d. allg. Path. u. path. anat. $13 \mathrm{Jg}$. II. Abt. 3) Ecker: Anat. Untersuch. über Chloroformschädig. d. Gehörorg. Arch. f. O. N. K. hk. Bd. 118. 4) Fischler: Über den Fettgehalt von Niereninfarkt usw. Virchows Arch. Bd. 170. 5) 海江田 :

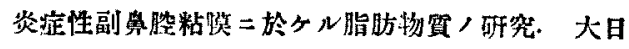

\section{献}

耳鼻，第36卷. 6) 川㭙：人體及ビ動物體内二於 タル脂肪問題二就デ云々. 日新琶學，第7卷.7)末

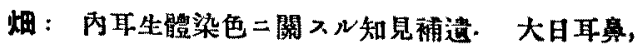
第33兊. 8) Kusnetzowsky: Über die Ablag. der Lipoide in den Sihnen. Virchows Arch. Bd. 203. 9) Derselbe: Über Tuschspeicherung im Bindegewebe bei aktiver Hyperämie u. Ent2uendung. Ziegler Beit. Bd. 83. 10) 中道: 器二於ヶル脂肪分布二就テ，䓟監的研究.耳鼻臨 朋，第14卷．11）中道：聽器細菌性炎二於々儿形 


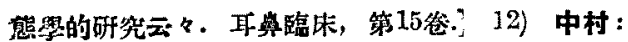

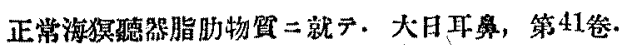

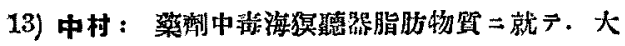
日耳鼻，第41怣. 14) 中村：內耳二輸入をヨレタ

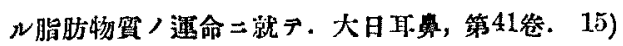
小田, 箖：「クロ、フォルム」外䤄道注入二因ル迷 路炎二就テ. 大日耳鼻, 第41卷. 16) 坂元：内耳生

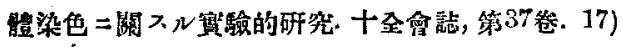

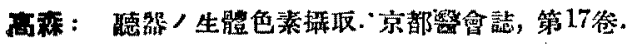

\section{附 圖 說 明}

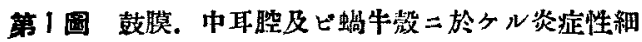
胞法出。第 4 號海㩧(外㯖道「口ロロフォルム」 注入12時間後) 谏䊅切片「ズダン・ヘマトキシリ ン」筑染色。(ツフイス $3 \times 5,32 \mathrm{~cm})$ 。鼓膜表皮

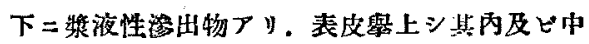

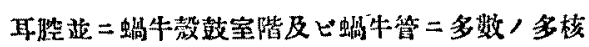
白血球遊出 今其原形賀二脂肪顆䉼 $\neq$ 有入。

第2 圖中耳腃) 炎症性淁出細胞。第 27 號海㩧(中 耳細菌注入 48 時間後) 濑結切片.「ズダン・ヘマ

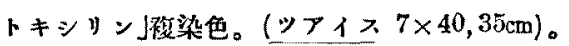
多核白血球及七゙組峨球性細胞二多數 キ認么。

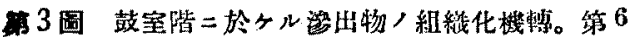

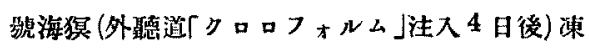
絬切片.「ズダンーマトキシリン」檴染色.（ツ >1> $7 \times 20,20 \mathrm{~cm})$ 。多核白血球. 組䋊球性細胞 及ビ新生絬維緎細胞二多是/脂肪顆粒認么。

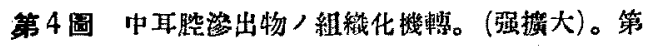
15 號海猽 (外聽道「クロロフォルム」注入 1 タ月

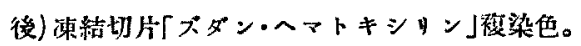
(ツアイス $7 \times 90,24 \mathrm{~cm}$ )。組織球性細胞及ビ新 生結䋨蟣細胞二多數，脂助顆粒斗認么。

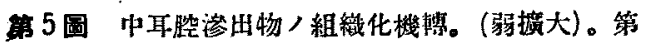

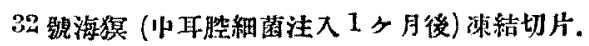

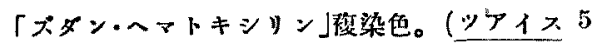
$\times 40,20 \mathrm{~cm})$ 。多核白血球／周图二組緎球性細胞 集合シ其原形貿二多量入脂助顆粒ア日。結綰絨 細胞 之二接シア其新生盛ナル部位二へ多量

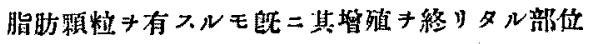
(圆监左下方) ニハ少シ。

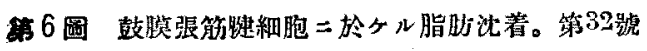

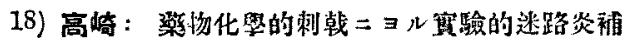

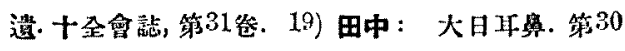

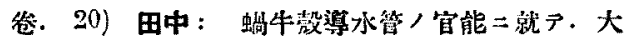

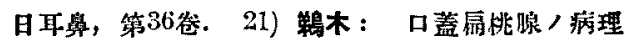

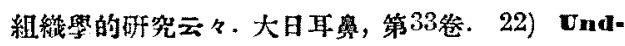
ritz: Über inducierte Labyrinthitis beim Meerschweinchen Zeitschr. f. H. N. O-hk. Bd. 22.

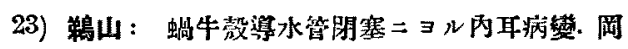
山䝷會誌, 第521號.

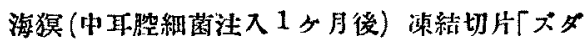

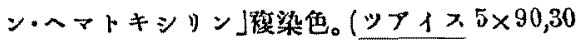

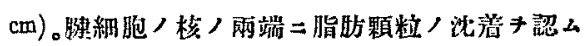

第7 圖正常海䐎䌡骨前庭關節靯骨細胞。凍結切片 「ズダン・ヘトキシリン」殿染色。(ッフイス7

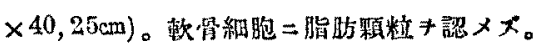

第 8 圖 鐙骨前庭閔節軟骨細胞二於ヶル脂肪沈着。 第 32 號海猽 (中耳腔細菌注入 1 ヶ月後) 凍結切 片.「ズダン・ヘトキシリン」磞染色。(ツア1

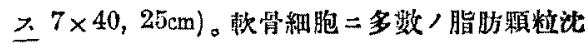
福七り。

事9圆歐比管上皮細胞二於タ儿脂肪沈着。第 31

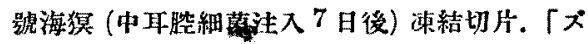

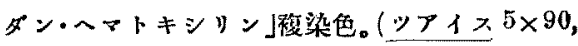
$18 \mathrm{~cm})$ 。上皮細胞二稍?多数〉脂肪沈着アリ。 管膛内二炎症性洷出物認么。歐氏管軟骨細胞 中八脂胞顆粒》正常動物二モ存在スッモノニシ テ. 荻症二八無閔保ナリ。

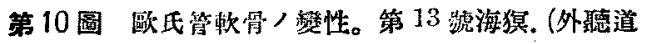
クロロフォルム」注入3ク月後) 涑結切片.「ズダ ン・ヘマトキシリン䃥染色。(ツアイス $7 \times 20$,

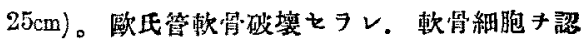
メザルモ。其脂肪影粒八残存入。粘膜上皮細胞 八完全二再生をり。

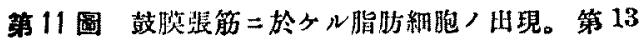

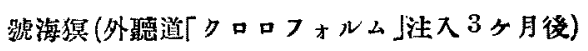
湅結切片.「ズダン・ヘマトキシリン」不染色。

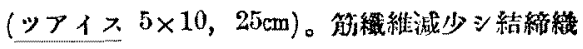
晢殖七ル外極メシ多数，脂肪細胞出现セツ。

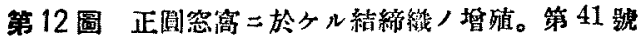

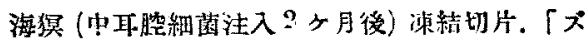




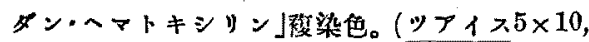

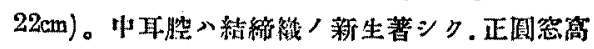

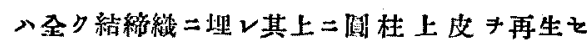

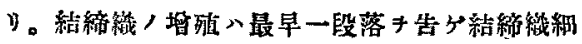
胞二ハ殆ンド脂肪顆粒キ認メプ。

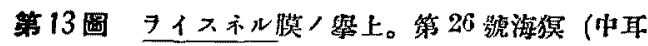

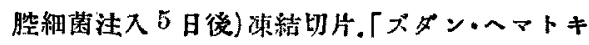
シリン」激染色。(ツアイス $3 \times 5,32 \mathrm{~cm})$ 。中耳-

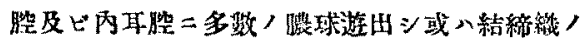

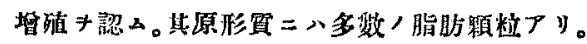
ヨイス采膜著シク舉上七り。

第 14 圖 蛸牛款導水管，閒塞。第 26 號海㩧 (第 13 圆卜间一動物) 凍結切片「ズダン・ヘマトキシリ

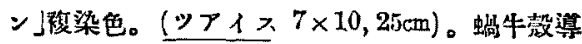
水管八牛分八網狀織細胞／堆殖二ョり。（圆中上

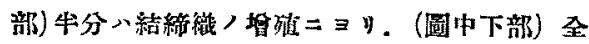

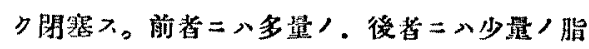

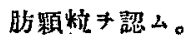

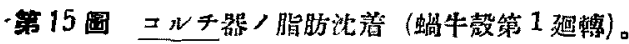

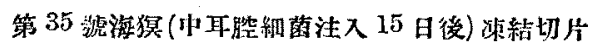
「ズダン・ヘマトキシりン」椱染色。(ッフイス $7 \times 20,27 \mathrm{~cm})$ 。鼓室前庭雨階二八炎症性渗出細 胞及ビ新生結維織細胞キ認メ其原形椞二脂肋顆

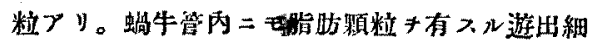
胞为認ムル外其上皮紐胞至ルトコロ二脂助顆䉼

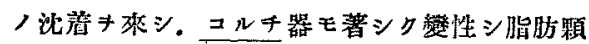
䊉出現入.

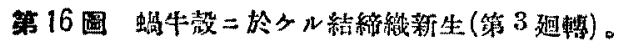

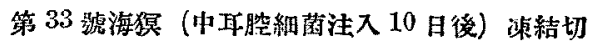

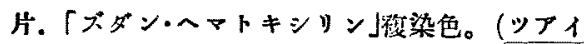

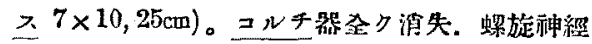

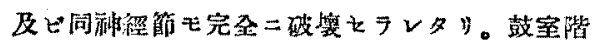

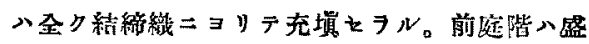

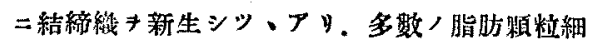
胞認么。

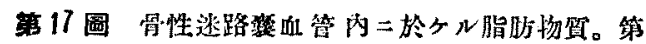

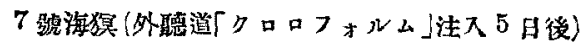

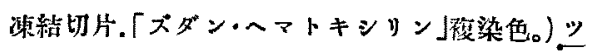

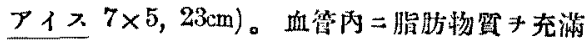
シ恰モ色䇣注入漂本キ見ルが如シ。

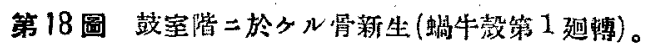

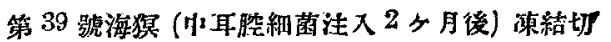
片、「ズダン・ヘマトキシリン搭染色。(ツブ1

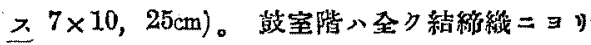
テ埋メラレ一部骨ノ新生キ來をり。結彎維中二

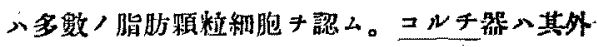
形斗保有七几有毛細胞消失をり。

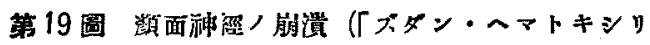

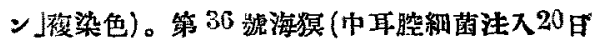
後）㶱結切片。(ツフィフ $7 \times 20,23 \mathrm{~cm})$ 。前庭 泙經ハ正常ニシテ「プダン」ニヨリテ淡染をルニ

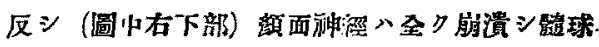

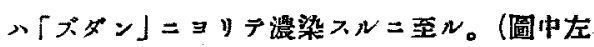
上部。

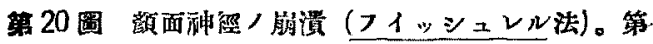

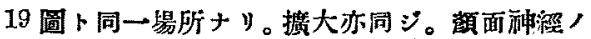

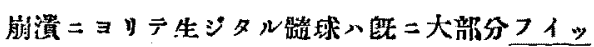

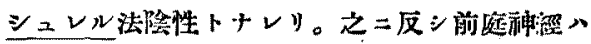
ヨク染レ川。

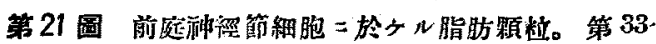

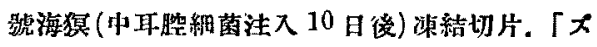
ダン・ヘトキシリン磼染色。(ツアイス $7 \times 90$,

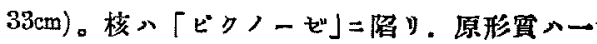

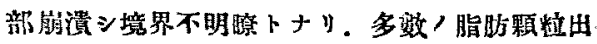
現入。

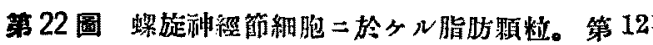
號海㩧(外聽道「クロロフォルA注入 4 日後) 東 結切片。「ズダン・マトキシリン棌染色。(ツ

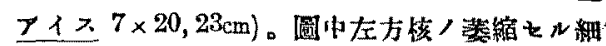
胞. 右方核〉膦化を心細胞及ビ上方二位スル細 胞(核八膨化をルモ。コ、ニ八見エプ）二脂肪顆， 粒产認么。

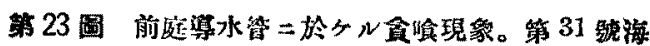

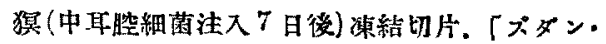
ヘマトキシリン」硙染色。(ツアイス $5 \times 90,30$

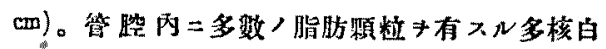
血球アリ一部八組織球性緗胞二捕全七タレタリ

第24圆小耳腔出物中二於々儿重㕍折性結晶。

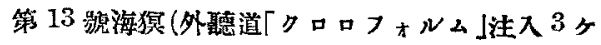

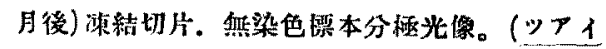

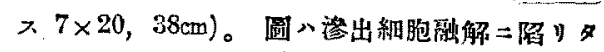
ル中央部ナリ。

(绵辌到着 $=$ 昭和 $10,3,31$ ) 


\section{中 村論文附圖 1}

Fig. 1.

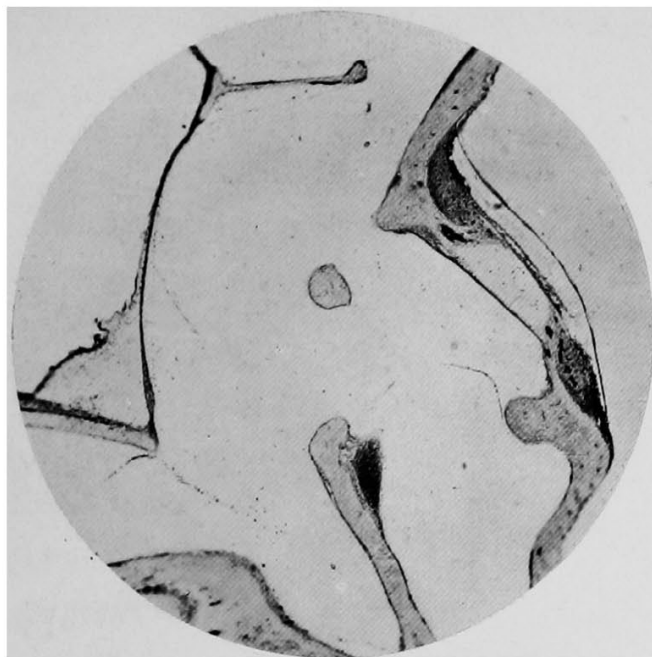

Fig. 3.

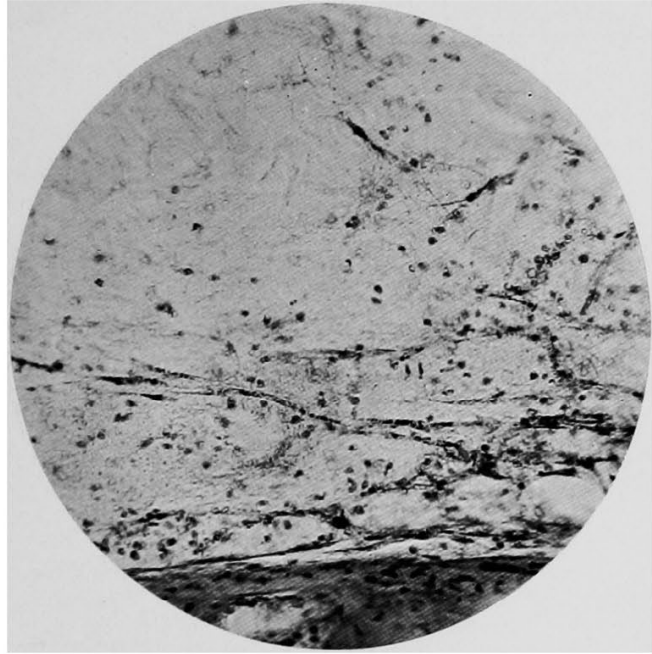

Fig. 5.

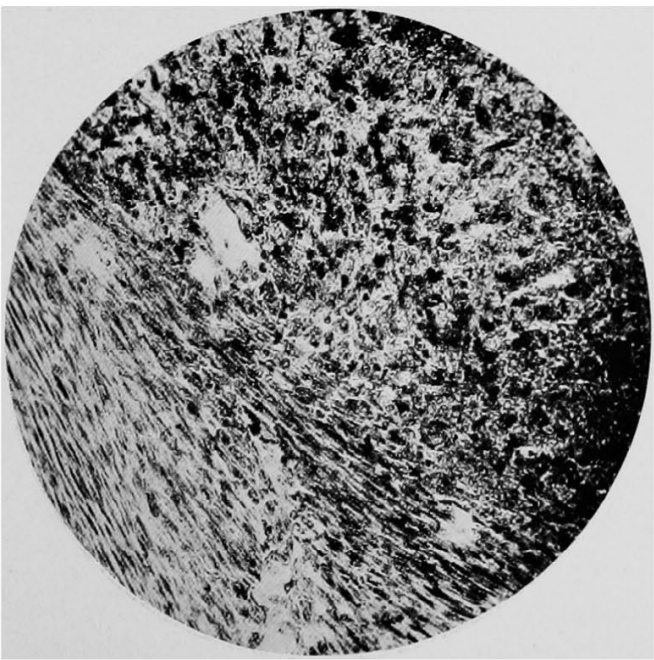

Fig. 2.

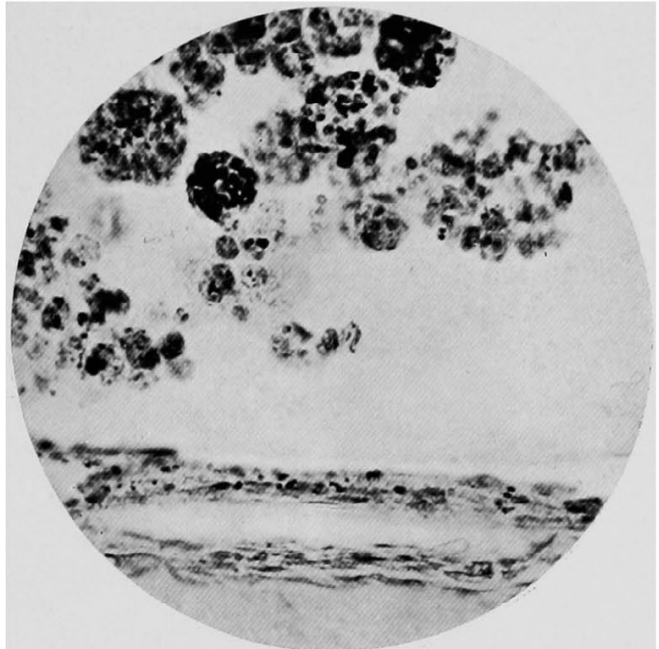

Fig. 4.

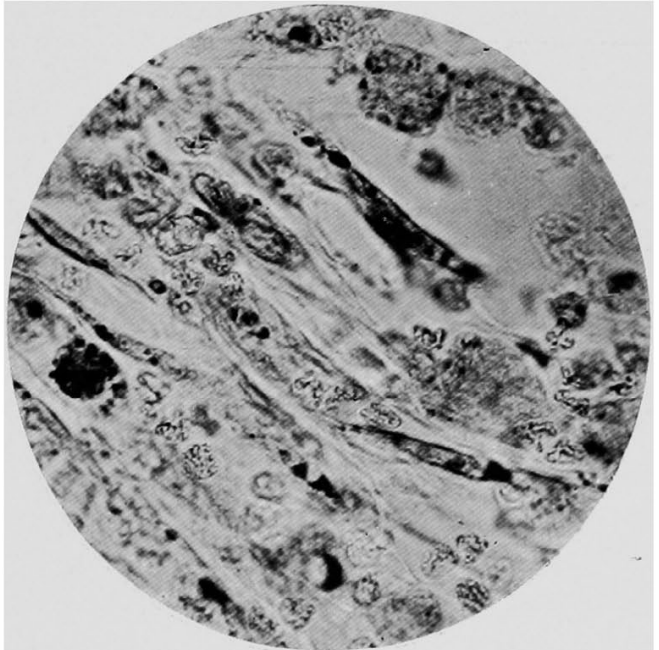

Fig. 6.

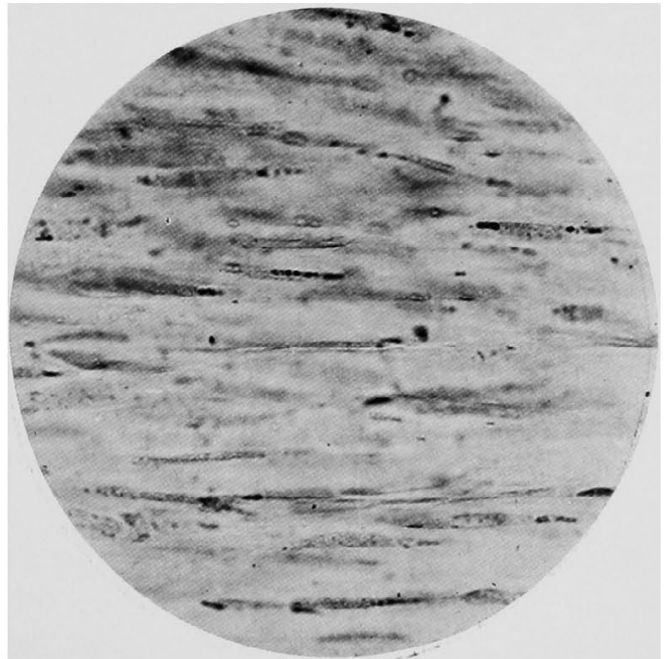

H. Nakamura: Experimentelle Untersuchungen über die Fettsubstanzen im Gehörorgan. III. Mitteilung: Über die Fettsubstanz im entzündeten Gehörorgan des Meerschweinchens. 
Fig. 7.

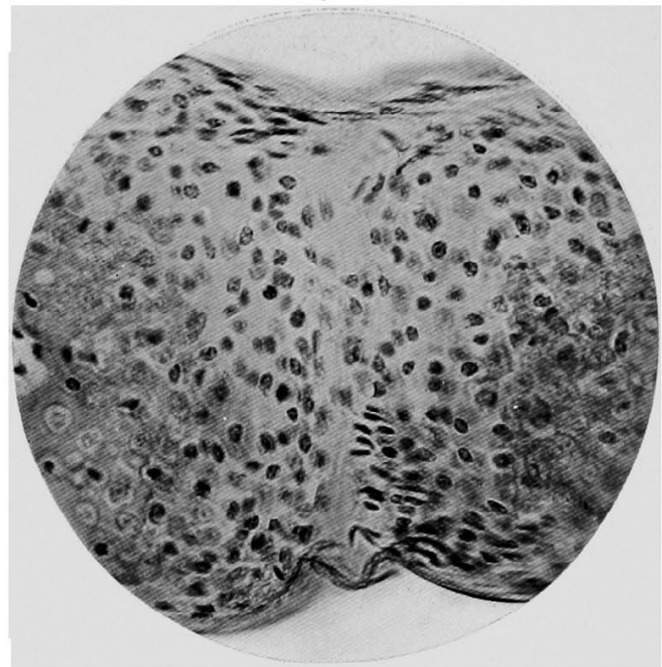

Fig. 9.

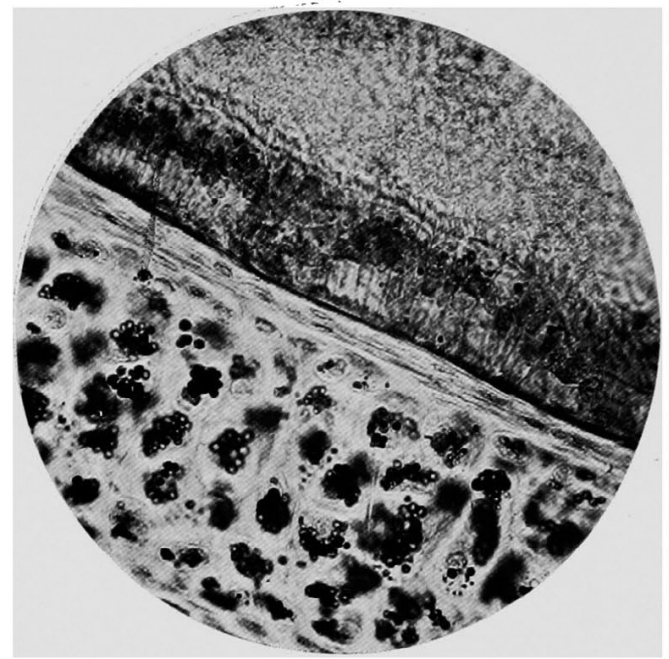

Fig. 11.

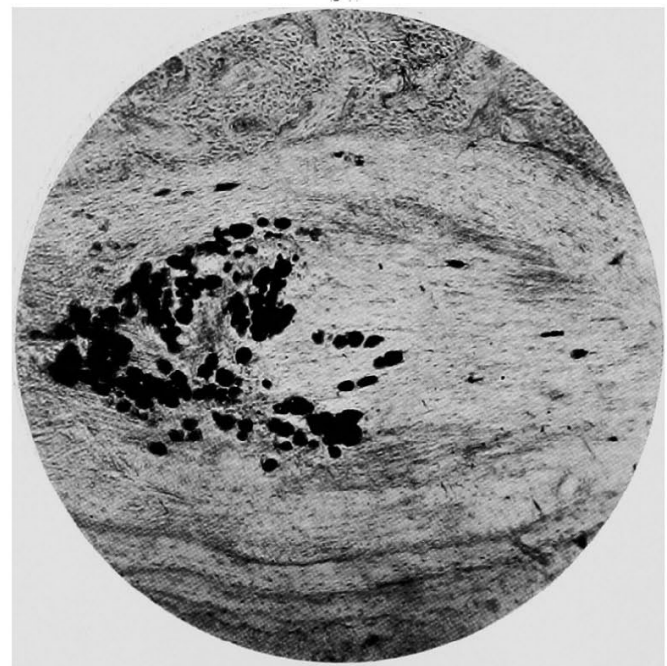

Fig. 8.

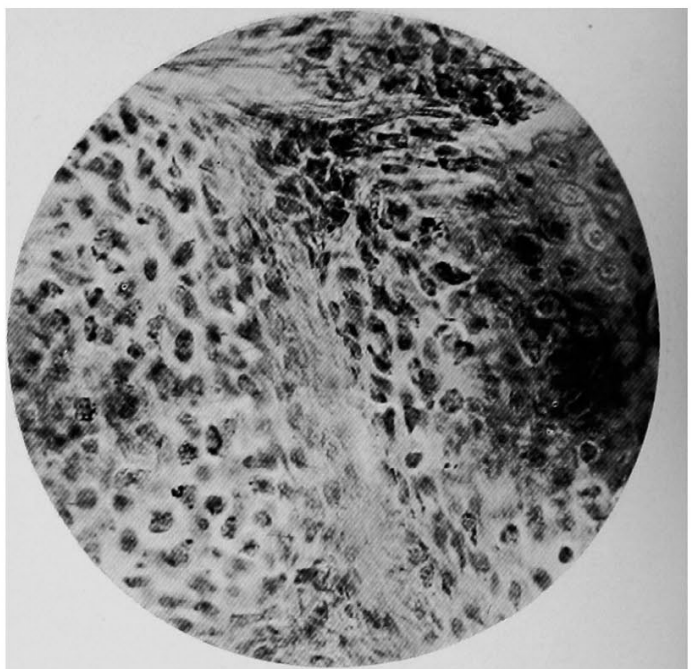

Fig. 10.

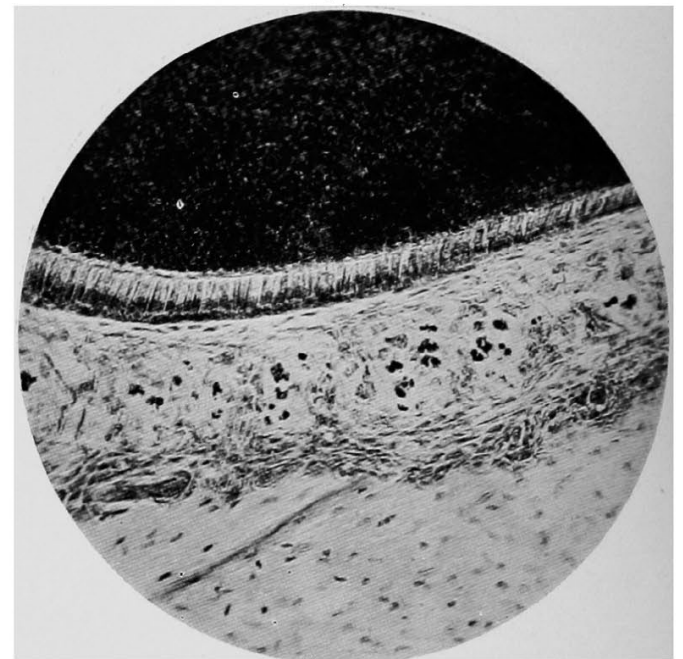

Fig. 12.

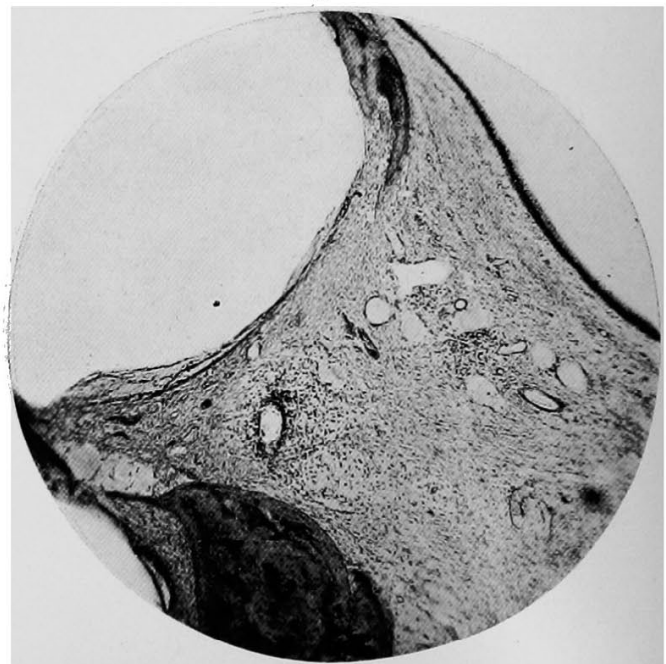

H. Nakamura: Experimentelle Untersuchungen über die Fettsubstanzen im Gehörorgan. III. Mitteilung: Ü̉ber die Fettsubstanz im entzündeten Gehörorgan des Meerschweinchens. 


\section{中 村 論 文 附 圖 3 .}

Fig. 13.

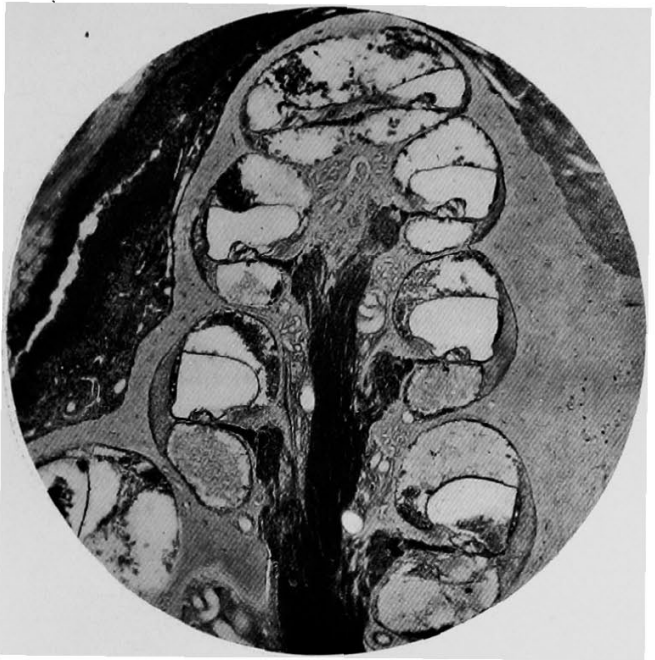

Fig. 15.

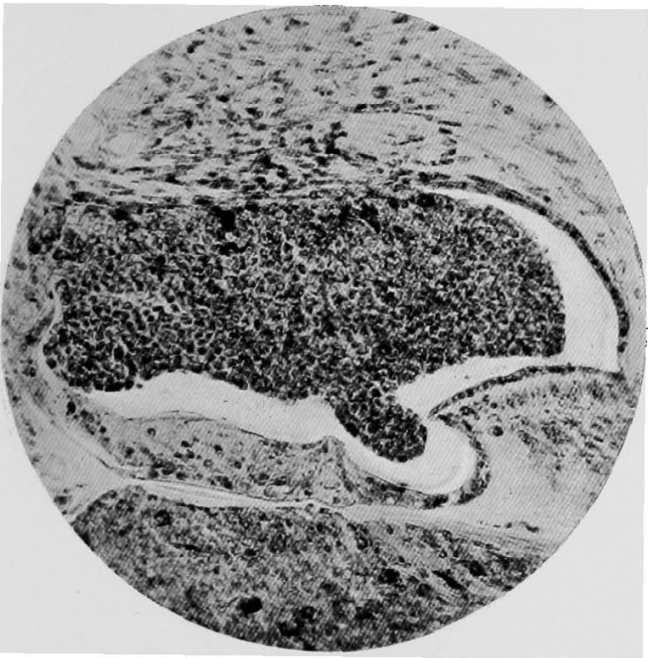

Fig. 17.

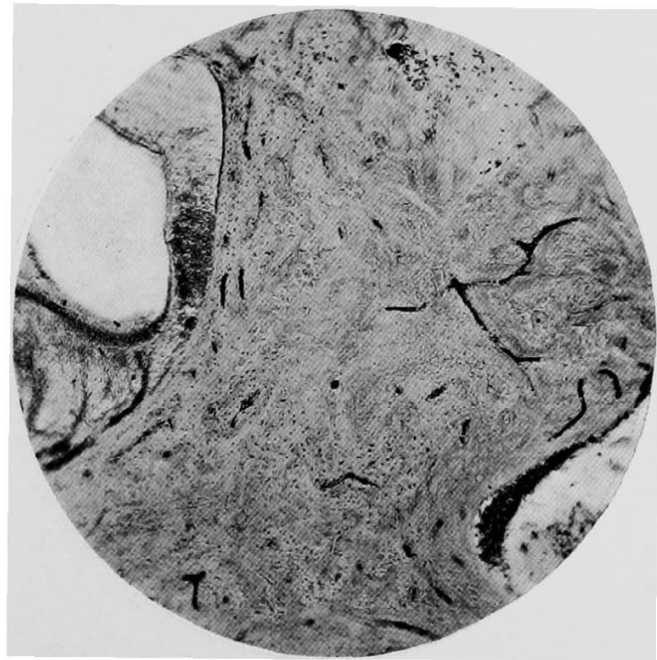

Fig. 14.

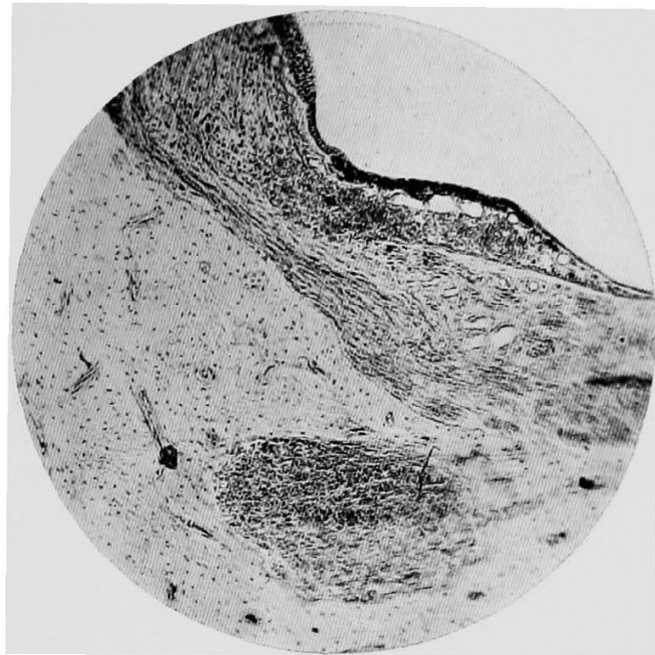

Fig. 16 .

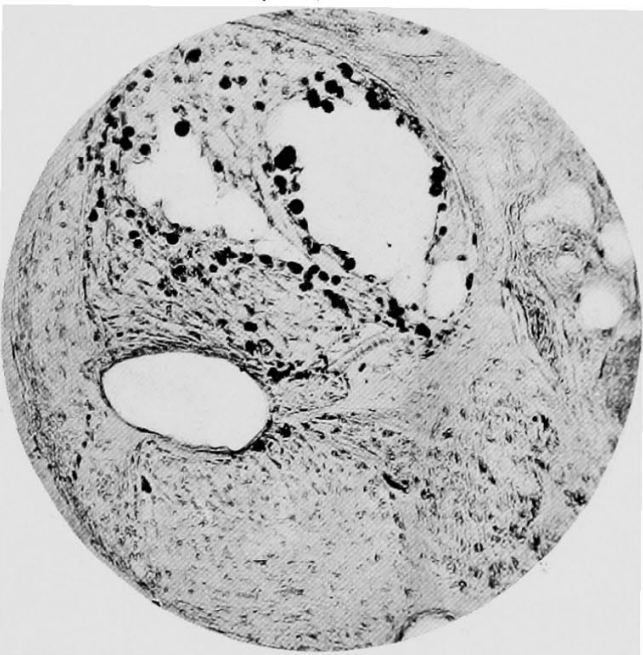

Fig. 18

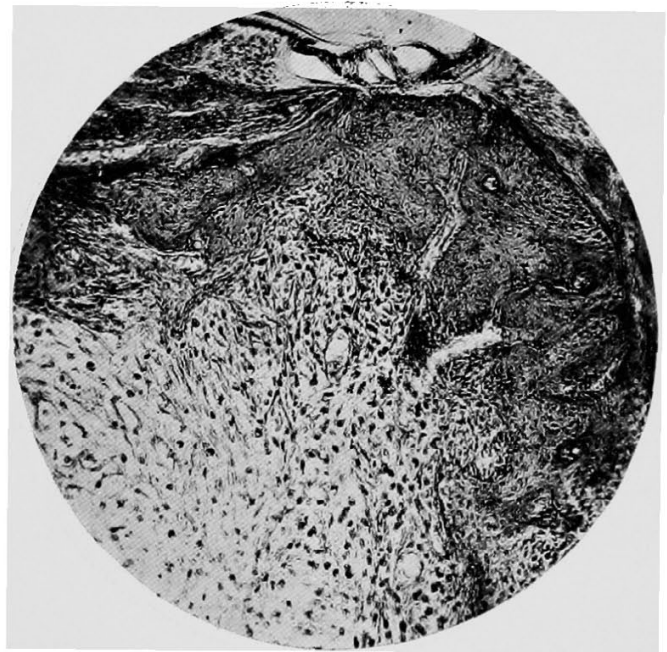

T. Nakamnra: Experimentelle Untersuchungen über die Fettsubstanzen im Gehörorgan.

II. Mitteilung: Über die Fettsubstanz im entzündeten Gehörorgan des Meerschweinchens. 


\section{中 村 論 文 附 圖 4 .}

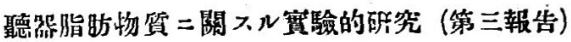

Fig. 19.

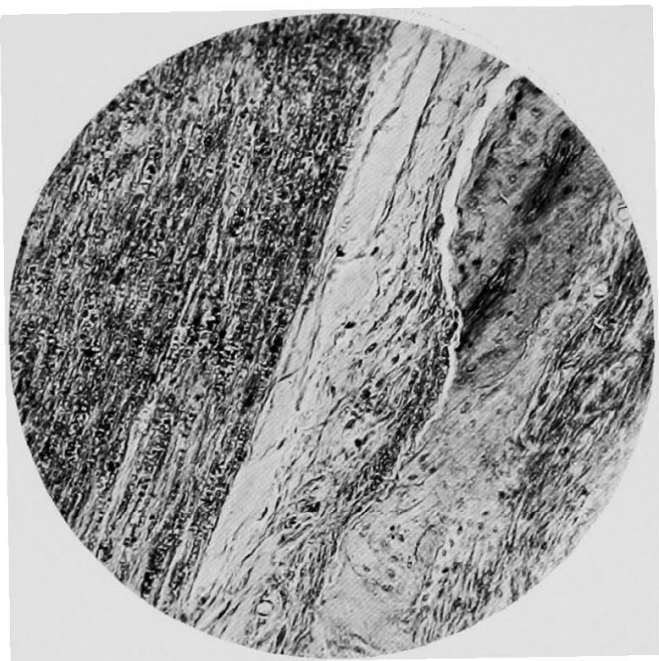

Fig. 21.

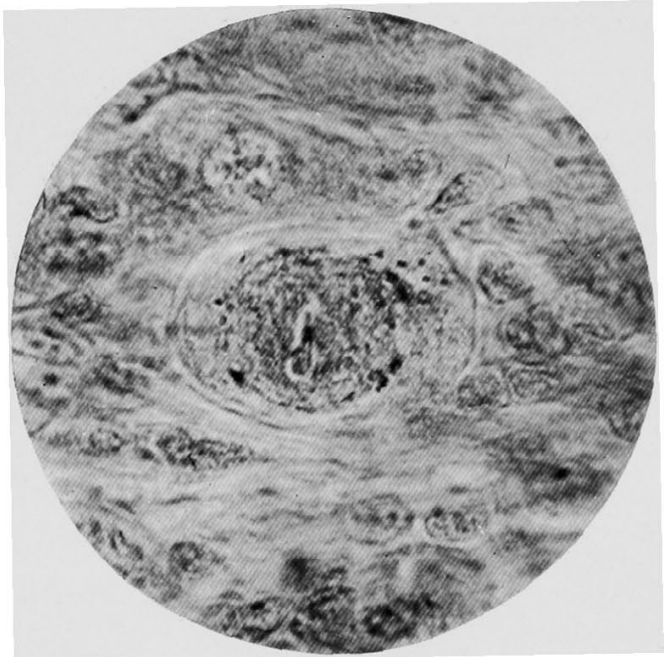

Fig. 23.

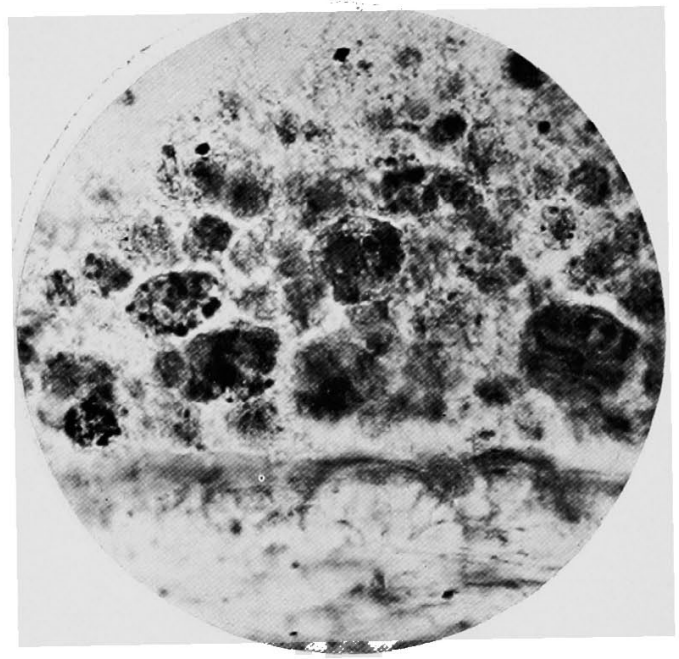

Fig. 20.

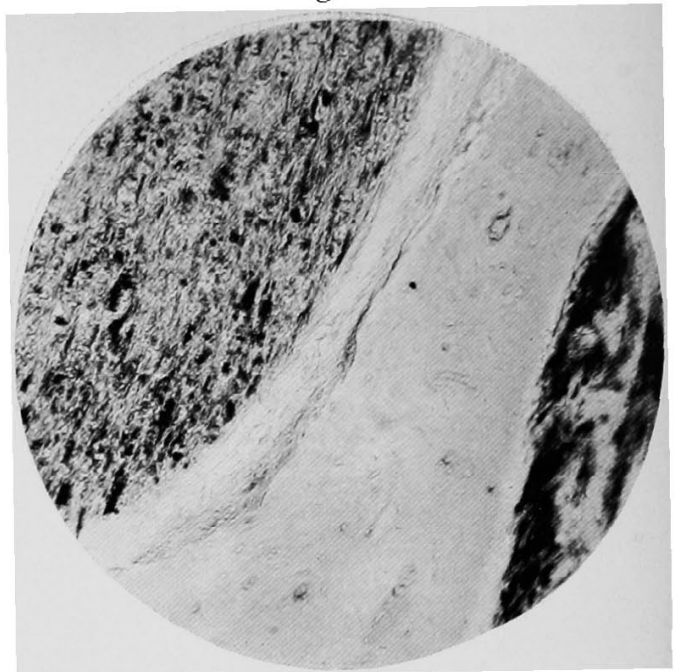

Fig. 22.

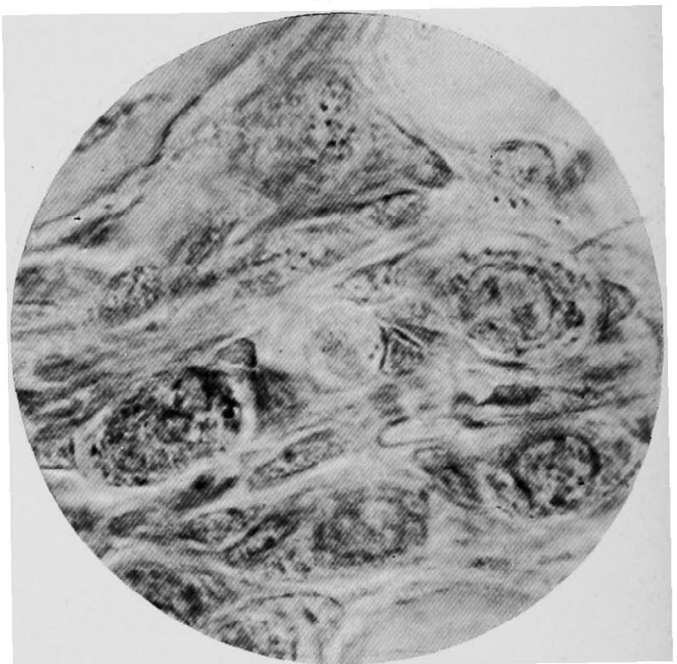

Fig. 24.

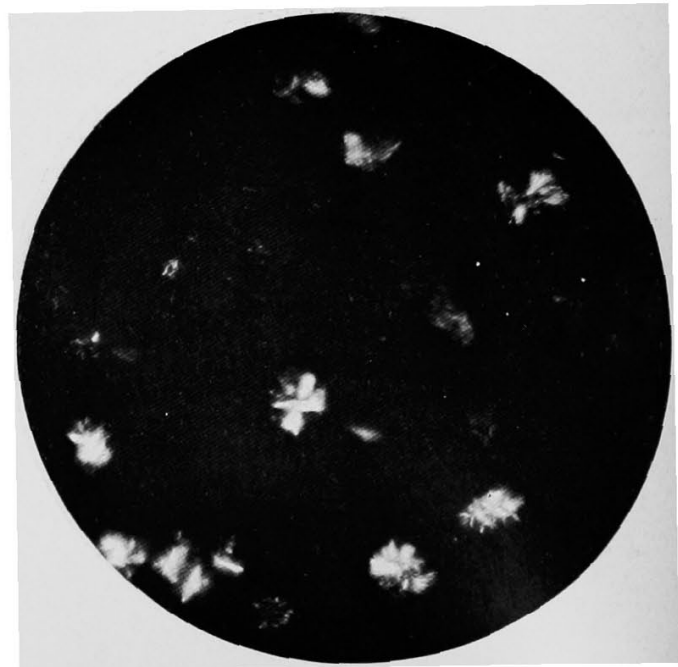

H. Nakamnara: Experimentelle Untersuchungen über die Fettsubstanzen im Gehörorgın.

III. Mitteilung: U̇ber đie Fettsubstanz im entzündeten Gehörorgan des Meerschweinchens. 